\title{
Conceptual model of the Şavşat (Artvin/ NE Turkey) Geothermal Field developed with hydrogeochemical, isotopic, and geophysical studies
}

\author{
Fatma Gültekin ${ }^{1 *}$, Esra Hatipoğlu Temizel ${ }^{1}$, Ali Erden Babacan², M. Ziya Kırmacl ${ }^{1}$, Arzu Fırat Ersoy \\ and B. Melih Subaş ${ }^{1}$
}

\section{*Correspondence:}

fatma@ktu.edu.tr

${ }^{1}$ Geological Engineering

Department, Karadeniz

Technical University, Trabzon,

Turkey

Full list of author information

is available at the end of the

article

\begin{abstract}
The Şavşat (Artvin, Turkey) Geothermal Field (ŞGF) is located on the northeastern border of Turkey. This field is characterized by thermal and mineralized springs and travertine. The temperature of the thermal water is $36^{\circ} \mathrm{C}$, whereas that of the mineralized spring in the area is approximately $11^{\circ} \mathrm{C}$. The $\mathrm{Na}-\mathrm{HCO}_{3}-\mathrm{Cl}$-type thermal water has a pH value of 6.83 and an EC value of $5731 \mu \mathrm{S} / \mathrm{cm}$. The aim of this study is to characterize the geothermal system by using geological, geophysical, and hydrogeochemical data and to determine its hydrochemical properties. A conceptual hydrogeological model is developed for the hydrogeological flow system in the ŞGF. According to the hydrogeological conceptual model created by geological, geophysical, and hydrogeochemical studies, the reservoir comprises volcanogenic sandstone and volcanic rocks. The cap rock for the geothermal system is composed of turbiditic deposits consisting of mudstone-siltstone-sandstone alternations. An increase in the geothermal gradient is mainly due to Pleistocene volcanic activity in the field. The isotopic values of thermal water $\left(\delta^{18} \mathrm{O}, \delta^{2} \mathrm{H}, \delta^{3} \mathrm{H}\right)$ indicate a deeply circulating meteoric origin. The estimated reservoir temperature calculated by silica geothermometers is $100-150^{\circ} \mathrm{C}$, and the mixing rate of cold groundwater with geothermal waters is approximately $70 \%$. It may be possible to obtain warmer fluids from a 300-m-deep borehole cutting through a fracture zone identified by geophysical studies. Heating by conduction via the geothermal gradient resulting from young volcanic activity drives geothermal waters upwards along faults and fractures that act as hydrothermal pathways. The positive ${ }^{13} \mathrm{C}_{\mathrm{VPDB}}$ value $(+4.31 \%)$ indicates a metamorphic origin for the thermal water. The ${ }^{34} \mathrm{~S}_{\mathrm{CDT}}$ value $(\sim 10 \%)$ shows that the sulfur in the geothermal water is derived from volcanic sulfur $\left(\mathrm{SO}_{2}\right)$.
\end{abstract}

Keywords: Geothermal, Hydrogeochemistry, Hydrogeological conceptual model, Geophysical studies, Şavşat (Artvin-Turkey) 


\section{Introduction}

The Şaşsat Geothermal Field (ŞGF) is located in northeast Turkey on the border with Georgia (Fig. 1). According to meteorological data from the closest station to the study area in the town of Şavşat, the mean annual precipitation is $580 \mathrm{~mm}$, and the mean annual temperature has been $9.9^{\circ} \mathrm{C}$ for the last 10 years (MGM 2017). The older units of the study area are Late Cretaceous-age volcanic rocks (Güven 1993), Paleocene-early Eocene-age sedimentary rocks (Erendil et al. 1989), and middle Eocene-age andesite and basalt-type volcanic rocks and volcanogenic sandstones (Güven 1993). Young units are Lutetian-age turbidites (Erendil et al. 1989) and Oligo-Miocene-age sedimentary rocks, including sandstone, siltstone, and marl alternations (Karaköse et al. 1994; Konak et al. 1998). Previous studies in the area (Kara 1997; Akkuş et al. 2005) reported thermal springs with temperatures of nearly $36{ }^{\circ} \mathrm{C}$. These springs have been used for many years in primitive facilities for balneological purposes by local people. During field studies, thermal springs were observed at different locations along the Çermik Stream valley with temperatures ranging from 20 to $36^{\circ} \mathrm{C}$. In recent years, private undertakings that run mountain plateau tourism (or yayla) in the area have wanted to obtain warmer water to provide better service to the region. With this aim, drilling studies were performed in 2016 , and water with temperatures of nearly $39^{\circ} \mathrm{C}$ was obtained from $120 \mathrm{~m}$ depth. This well, drilled immediately beside the thermal spring, caused the spring to dry up. In this area, apart from some information included in the Geothermal Energy Inventory of the Turkish Geological Survey (MTA), there has not been any study to date that assesses the geothermal, hydrogeological, or hydrogeochemical properties. To define the geothermal system and its surroundings, it is important to determine the hydrogeological, hydrochemical, and isotopic properties. Geological and geophysical studies and

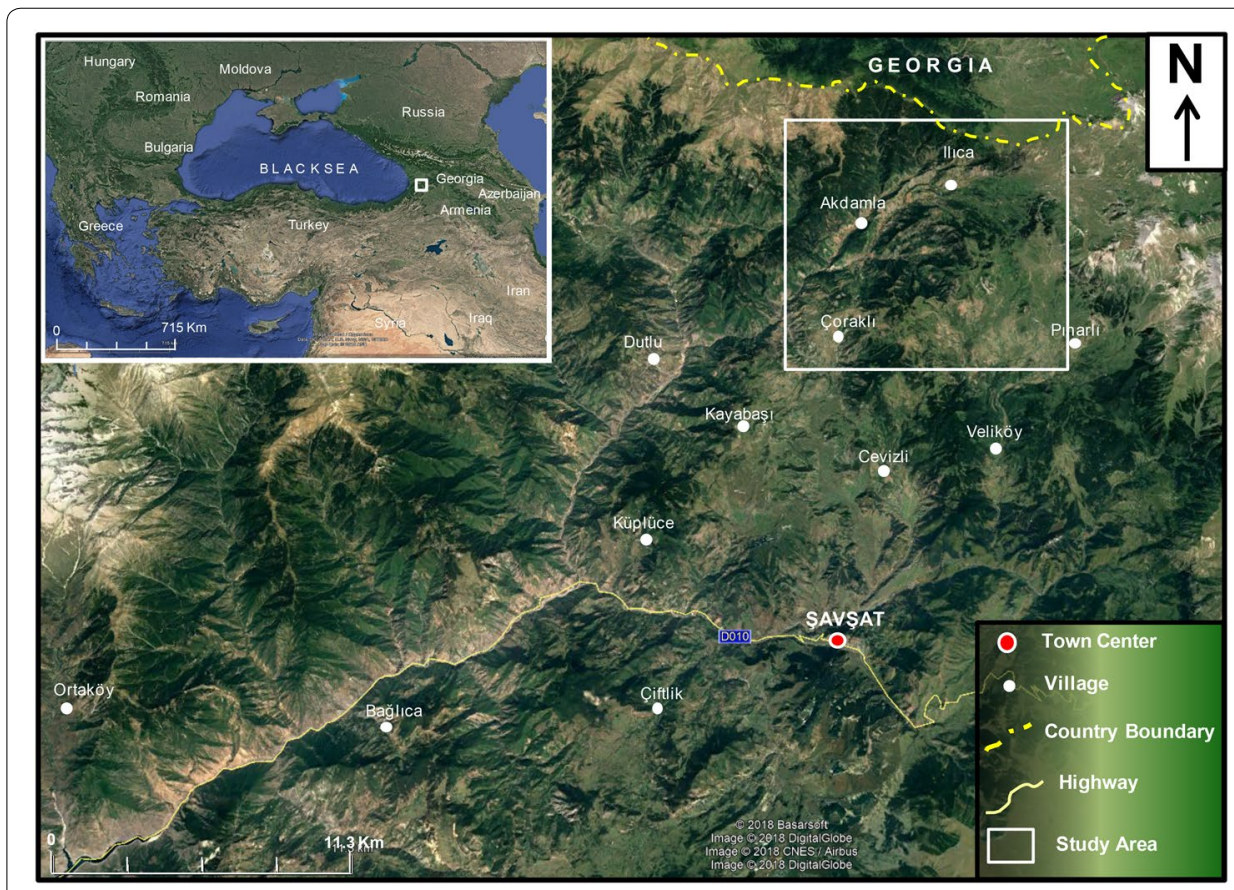

Fig. 1 Location map of the Şavşat (Artvin/Turkey) Geothermal Field 
hydrogeochemical and isotope techniques have been widely used elsewhere to determine the hydrodynamic structure of geothermal systems in recent years (Tarcan et al. 2005; Piscopo et al. 2006; Schaffer and Sass 2014; Yurteri and Şimşek 2017; Uzelli et al. 2017). In this geothermal field, there has not been any study that employs a conceptual approach based on hydrogeological and hydrogeochemical studies, such as hydrochemical facies compositions, isotopic features, water-rock interactions, mixing processes, and reservoir temperature. This study focuses on understanding the mechanism of the geothermal system in the ŞGF for future use, determining the areas with higher temperatures and revealing the hydrogeochemical characteristics of the geothermal water. In accordance with this purpose, geological, geophysical, and hydrogeochemical studies were performed in the area to characterize components such as the reservoir, geothermal fluids, and cap rock of the geothermal system. Establishing a hydrogeologic conceptual model can further help to determine flow paths, including recharge through flow-discharge processes, as well as mixing behavior.

\section{Methodology}

Field studies were completed in three different forms: geological studies, geophysical studies, and measurements and sampling on site. Geological studies were carried out on 1/25,000-scale topographic maps and 1/100,000-scale geological maps of the study area prepared previously by a variety of researchers. Geological units were observed in the field, and the geological maps made by different researchers were revised. Rock samples were taken for lithological identification. During field studies, observations and geologic-tectonic studies of the area were used to identify sample locations for thermal, cold, and surface waters. To determine the chemical content and variations of the geothermal and cold waters, samples were taken from each location to represent rainy, dry, and interval periods from May 2016 to October 2017, and measurements were performed in the field.

In-situ measurements and sampling were performed at the geothermal well (ILICAS), in mineral water within the basin (GMS), in mineral water outside the basin (CDMS), in cold spring water (SSSK, GSK), and in the Çermik Stream before (CERDERY) and after (CERDERA) thermal water mixing. The coordinates of each sampling location were recorded by a handheld GPS and marked on a geological map.

Measurements of temperature (T), electrical conductivity (EC), pH, total dissolved solids (TDS), and dissolved oxygen (DO) at the sampling points were performed with a YSI556 multiparameter meter. The probes used during the measurements were preserved by washing them with pure water before and after each measurement and were used after daily calibrations with buffer solutions. All water samples were filtered through $0.45 \mu \mathrm{m}$ membranes on site. To determine the major anion-cation and trace element contents of the waters, samples were taken with polyethylene (HDPE) bottles. For major anion-cation and trace element analysis, $500 \mathrm{~mL}$ and $50 \mathrm{~mL}$ bottles were used, respectively. Nitric acid $\left(\mathrm{HNO}_{3}\right)$ was added for cation and trace element analysis to bring the $\mathrm{pH}$ to $<2$. Major anion-cation, trace element, and tritium $\left({ }^{3} \mathrm{H}\right)$ analyses were carried out at the Water Chemistry Laboratory at Hacettepe University (Turkey) using the following methods: major cation analysis $\left(\mathrm{Ca}^{2+}, \mathrm{Mg}^{2+}, \mathrm{Na}^{+}\right.$, and $\left.\mathrm{K}^{+}\right)$was performed by atomic absorption spectrometry. $\mathrm{Cl}^{-}$was analyzed using an $\mathrm{AgNO}_{3}$ titrimetric method. Sulfate 
concentrations were determined by spectrophotometry together with alkalinity standard titration methods, whereas $B$ and $\mathrm{SiO}_{2}$ were analyzed with the spectrophotometric method. The major ion balance error of the analyses was less than 5\%. Trace element analysis was performed with the inductively coupled plasma-mass spectrometry (ICPMS) method.

Samples of $100 \mathrm{~mL}$ for $\delta^{18} \mathrm{O}, \delta^{2} \mathrm{H}$, and $\delta^{13} \mathrm{C}$ analyses and samples of $500 \mathrm{~mL}$ for $\delta^{3} \mathrm{H}$ analysis were collected. For the $\delta^{34} \mathrm{~S}$ analysis, $250 \mathrm{~mL}$ to $1000 \mathrm{~mL}$ samples were collected based on the amount of sulfate in the waters. The samples were kept cold until they were sent to the laboratories. A snow sample was taken by immersing a cylindrical tube into the snow. Then, this snow mass was poured into a polyethylene container and kept at $+4{ }^{\circ} \mathrm{C}$ until it became liquid. $\delta^{18} \mathrm{O}, \delta^{2} \mathrm{H}$, and $\delta^{13} \mathrm{C}$ isotopic analyses were performed at the Iso-Analytical Laboratory in the UK using the isotope ratio mass spectrometry (IRMS) method. For geothermal water, the $\delta^{18} \mathrm{O}$ and $\delta^{34} \mathrm{~S}$ analyses of the sulfate were performed by the Isotope Tracer Technologies Inc. (Canada) laboratory using the IRMS technique. Standard deviations of the stable isotope analyses were $0.11 \%$ for ${ }^{18} \mathrm{O}$ and $0.90 \%$ for deuterium.

The AquaChem 2012.1 program was used to evaluate the results of the chemical analyses, to prepare diagrams and to calculate the saturation indices (SI) of selected minerals.

In recent years, geophysical methods have been commonly used in the investigation and development of geothermal resources, especially with the development of technology, and these methods have provided successful results (Majumdar et al. 2000; ElQuady 2006; Özürlan and Şahin 2006; Drahor and Berge 2006; Abiye and Haile 2008; Wu et al. 2012). Although many geophysical methods are used in geothermal fields, electrical resistivity is one of the most preferred methods for investigating many geothermal fields. High temperatures and water flow in geothermal systems change electrical conductivity properties underground. Due to these changes, it is possible to obtain important information about the location, depth, and structure of geothermal resources by using the electrical resistivity method. Electrical resistivity is one of the most widely used geophysical methods in underground surveys (Telford et al. 1990; Reynolds 1997). In this method, the basic principle is to send a known current through two current electrodes into the ground and measure the voltage difference with two potential electrodes. From these measured potentials, the calculation of the resistivity and thickness of the underground layers is based on Ohm's law. The resistivity distribution of the underground materials is measured by the resistivity method. Two-dimensional (2D) resistivity images of the underground layers are obtained by using a large number of electrode pairs in the electrical resistivity tomography method (ERT). This method is a very effective and widely used method for identifying lateral and vertical changes, presence and level of groundwater, hot springs, salinity, cavities, and weathered rocks (Reynolds 1997; Aizawa 2014).

In the field, a pole-to-pole electrode array was used along the three profiles with a total profile length of $600 \mathrm{~m}$, and 2D ERT data were acquired with an Advanced Geosciences, Inc. (AGI) SuperSting R8-IP (Figs. 2, 3). The power supply of this device consisted of a transmitter unit capable of producing a $2000 \mathrm{~mA}$ current with $400 \mathrm{~W}$ power and a special generator with $4 \mathrm{kWA}$ power. The electrical resistivity measurements targeted a research depth of approximately $300 \mathrm{~m}$. 

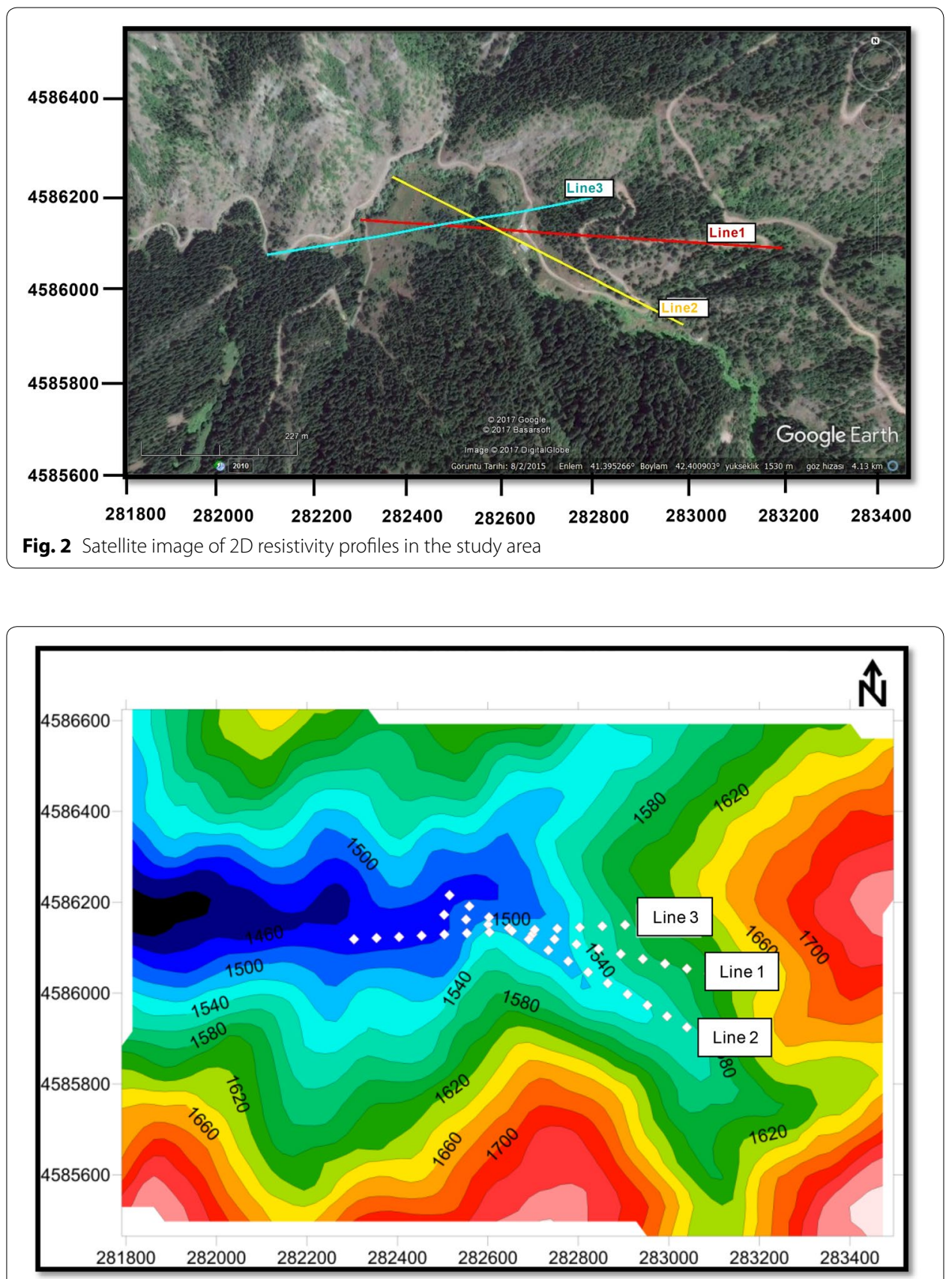

Fig. 3 The appearance of 2D resistivity lines on topography map

\section{Results and discussion}

\section{Geological and hydrogeological settings}

The Late Cretaceous-age Kizılkaya Formation comprises dacite, dacitic pyroclastics and volcanogenic siltstone, sandstone, and pebblestone (Güven 1993). The Paleocene-early Eocene-age Ardanuç Formation, which contains limestone, sandstone, tuff, and claystone intercalations, overlies the Mesozoic units (Fig. 4). The thin- and medium-bedded unit has a total thickness of $200 \mathrm{~m}$ (Erendil et al. 1989). 


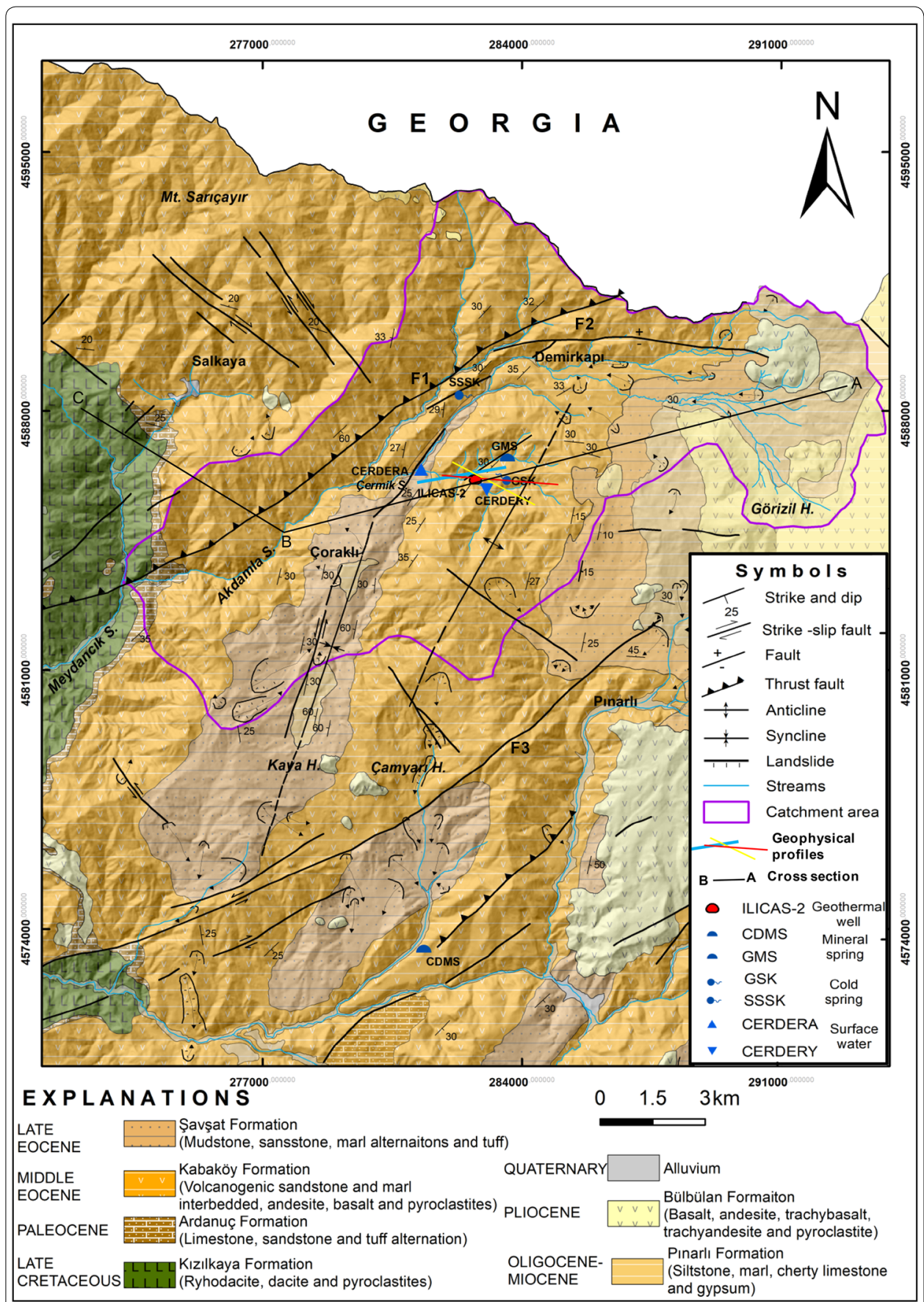

Fig. 4 Geological map of the Şavşat (Artvin/Turkey) Geothermal Field (revised from Erendil et al. 1989 and Konak et al. 1998)

The Lutetian (middle Eocene)-age Kabaköy Formation conformably overlies the Paleocene units (Güven 1993). The Kabaköy Formation, which outcrops widely in the study area, contains volcanogenic sandstone and pyroclastics at the lower levels. After a thick mudstone layer, it continues upward with basaltic and andesitic rocks. The thickness of the volcanic rocks, mostly composed of augite basalts, is $200 \mathrm{~m}$. The total thickness of the Kabaköy Formation is over $800 \mathrm{~m}$ (Güven 1993). 
The Şavşat Formation, which outcrops as mudstone-siltstone-sandstone alternations with a turbiditic character, is Lutetian in age (Erendil et al. 1989). The thickness of the unit consisting of round, small pebbles at the bottom and sandstones, siltstone and marls of yellowish color in the upper part is $400 \mathrm{~m}$. The Pinarlı Formation (Karaköse et al. 1994; Konak et al. 1998), comprising sandstone, siltstone, marl, lacustrine cherty limestone, and gypsum lenses, unconformably overlies the turbiditic unit (Erendil et al. 1989). The thickness of the unit consisting mainly of sandstone and siltstone is approximately $300 \mathrm{~m}$. Marl, lacustrine cherty limestone intercalations, and gypsum lenses are generally observed in these gray and mediumbedded rocks. The Pınarlı Formation is late Miocene in age (Karaköse et al. 1994) and includes landslides of varying sizes. The Pliocene-Pleistocene Bülbülan Formation (Erendil et al. 1989) overlies older units and consists of basalt, andesite, trachybasalt, trachyandesite, and pyroclastics in the study area. Plagioclase microliths and a small number of augite microcrystals are observed in the groundmass consisting of volcanic glass in the trachybasalts. Calcite as a secondary mineral accompanies these minerals. Plagioclase, sanidine, hornblende, and opaque minerals are observed in the trachyandesites. In the trachyandesites, chlorite is observed as a secondary mineral. The Bülbülan Formation overlies the Şavşat and Pınarlı Formations, with an angular unconformity ranging between 400 and $1000 \mathrm{~m}$ (Konak et al. 1998). The youngest unit in the area is alluvium cropping out in narrow areas along valleys.

Both thrust and normal faults are observed in the area. Thrust faults have NE-SW trends, whereas normal faults occur in several different directions. In addition, folding is represented by anticlines and synclines with NE-SW axial trends.

Clastic sedimentary rocks and volcanic rocks dominate the study area. Sedimentary rocks with high primary porosity have varying permeabilities depending on the degree of cementation. Volcanic rocks have a low primary porosity (3-5\%), except where they are fractured by cooling and tectonic activities.

Tuffs belonging to the late Cretaceous Kizılkaya Formation are permeable, whereas dacite and rhyodacite are impermeable. The volcanogenic sandstones of the Kabaköy Formation, which are extensively exposed in the study area, have good permeability characteristics. Pyroclastic rocks also have high permeability. The volcanic rocks in the Kabaköy Formation are permeable where they have been subjected to tectonic and cooling activities. The open fractures allow the deep circulation of water due to locally enhanced vertical permeabilities. Due to its thickness, extent, and permeability, this unit is considered to be the most important aquifer in the area. The Şavşat Formation, with mudstone-siltstone-sandstone alternations, has very low permeability; therefore, it is evaluated as semipermeable. Marl and gypsum layers of the Pınarlı Formation are impermeable. This unit, acting as an impermeable cap rock, prevents heat loss and maintains water pressure. Forming high hills in the study area, volcanic units of the Bülbülan Formation are permeable where they are fractured.

Alluvium in the area is permeable, but it has insignificant groundwater storage capacities because its dimensions are small.

The most prevalent stream in the area is the Akdamla Stream. It merges with the Meydancık Stream outside the study area. The thermal spring is located in the Çermik Stream valley, which is the branch of the Akdamla Stream. 


\section{Geophysical studies}

Due to the physical changes, the electrical resistivity method is used to obtain significant information about the geothermal source location, its depth, and the discontinuous structures that are possibly faults and fractures/joints, which may be important for the geothermal system. With the aim of determining the locations and depths of structural elements providing channels for fluids to reach the surface in the ŞGF, the ERT method was applied to three profiles. Two of the profiles were oriented approximately in the north-south direction, and the third was in the east-west direction. The locations of the electrical resistivity profiles were primarily determined based on the geology, topography, and ground conditions in the study area. The study area is quite mountainous, and flat areas are quite limited. For this reason, the measurement profiles were located as much as possible in the flattest area. Furthermore, an attempt was made to plan measurement profiles in such a way that they were perpendicular to the faults indicated by previous geological studies (Erendil et al. 1989; Güven 1993; Karaköse et al. 1994; Konak et al. 1998). Because the terrain conditions did not allow an overly long profile length, the pole-pole array was preferred to obtain maximum depth information. The apparent resistivity data obtained from three profiles using electrical resistivity measurements were assessed with the Res2Dinv program (Loke 2010), and true resistivity values and depth information were obtained for the study area as a result of inverse solution processes. The RMS errors for the three profiles were below $15 \%$. The RES2DINV program is written to run as automatically and robustly as possible, requiring very few input parameters from the user (Loke 2000). The program uses the smoothness-constrained least-squares method inversion technique (Geotomo Software; DeGroot-Hedlin and Constable 1990).

As the topography varies in the measurement profiles in the study area, the elevation data for each electrode point were measured, and topography calculations were included in the inverse solution process. 2D inversion was applied to the apparent resistivity data obtained in the study area to create $2 \mathrm{D}$ underground resistivity images. The information obtained regarding the underground structure from the 2D resistivity images was interpreted by taking the high and low resistance values into account. Considering the high and low resistivity zones, fault zones and hot water regions were marked on the images (Fig. 5). Fault zones and low and high resistivity areas on the $2 \mathrm{D}$ resistivity images were compared with the lithology in an attempt to determine the structure of the geothermal source. Moreover, a 3D resistivity map (Fig. 6) was created from all 2D profiles, and a change in resistivity with depth was displayed. In the resistivity images, high resistivity, medium resistivity, and low resistivity values are shown with red, green, and blue colors, respectively. While the resistivity values range from 10 to $5000 \Omega \mathrm{m}$, the maximum penetration depth is approximately $300 \mathrm{~m}$. The study area is generally composed of volcanic rocks, and very high resistivity areas (red color) represent massive rocks. In contrast, very low resistivity areas (blue color) may show the presence of hot water. Moreover, 2D resistivity images (Lines 1 and 2) indicate a large fault zone.

The sections obtained by matching these profiles with the lithologies indicate (Fig. 5) very promising hot water regions between 150 and $300 \mathrm{~m}$ of horizontal distance on Line 1, 250 and $350 \mathrm{~m}$ on Line 2, and 1250 and $1350 \mathrm{~m}$ in areas of 

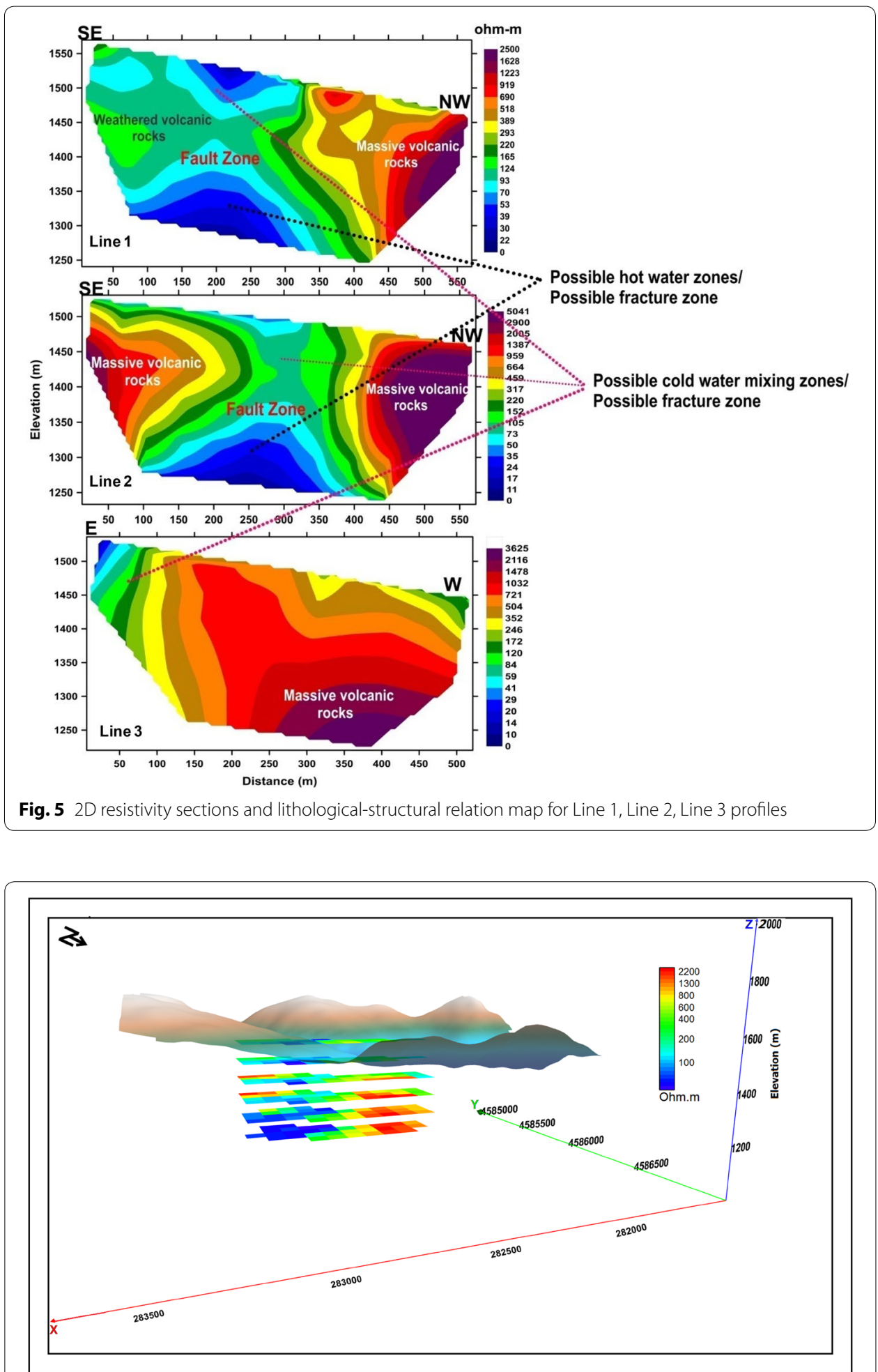

Fig. 6 3D resistivity map obtained from 2D profiles

topographic elevation. It appears that drilling to at least $300 \mathrm{~m}$ in this area would reach water with higher pressure and temperature than the present well and spring water. 


\section{Hydrogeochemical properties}

\section{Water chemistry}

Samples were taken from the thermal water output in the ŞGF to identify the chemical and isotopic characteristics of mineral and cold water springs. The water descriptions together with the coordinates and elevations of the sample locations are given in Table 1. Some properties of water, such as $\mathrm{pH}, \mathrm{T}, \mathrm{DO}, \mathrm{EC}$, and TDS, were measured at the sample locations in the field (Table 2). The mean values of $T, \mathrm{pH}$, and $\mathrm{EC}$ of the discharged waters from the artesian well (ILICAS) from $120 \mathrm{~m}$ depth were $37.5^{\circ} \mathrm{C}, 6.83$, and $5731 \mu \mathrm{S} / \mathrm{cm}$, respectively. In thermal waters dominated by $\mathrm{Na}$ and $\mathrm{HCO}_{3}$ ions, $\mathrm{SiO}_{2}$ was $97.65 \mathrm{mg} / \mathrm{L}, B$ was $44 \mathrm{mg} / \mathrm{L}$, F was $2.35 \mathrm{mg} / \mathrm{L}$, and $\mathrm{Li}$ and $\mathrm{Br}$ were $<1 \mathrm{mg} / \mathrm{L}$ (Table 2).

Ciritdüzü mineral water (CDMS) dominated by $\mathrm{Na}$ and $\mathrm{HCO}_{3}$ ions had a $\mathrm{pH}$ value of 6.42 , an $\mathrm{EC}$ of $3195 \mu \mathrm{S} / \mathrm{cm}, \mathrm{SiO}_{2}$ of $88.21 \mathrm{mg} / \mathrm{L}, B$ of $63 \mathrm{mg} / \mathrm{L}$, and $\mathrm{Li}, \mathrm{Br}$ and $\mathrm{F}$ of $<1 \mathrm{mg} / \mathrm{L}$. The GMS, which discharges into a swamp area, had an EC value of $522 \mu \mathrm{S} / \mathrm{cm}$, a pH of 7.58, and $\mathrm{SiO}_{2}$ of $26.4 \mathrm{mg} / \mathrm{L}$.

Cold spring waters (SSSK, GSK) had pH values of nearly 7.9 and EC values of 181.5 and $274 \mu \mathrm{S} / \mathrm{cm}$, respectively. These waters dominated by $\mathrm{Ca}$ and $\mathrm{HCO}_{3}$ ions contain $\mathrm{SiO}_{2}$ between 10.93 and $40.8 \mathrm{mg} / \mathrm{L}$ and $B$ values below $1 \mathrm{mg} / \mathrm{l}$ (Table 2).

The chemical characteristics of Çermik Stream water before (CERDERY) and after (CERDERA) mixing with geothermal water were different (Table 2). In the CERDERY water dominated by $\mathrm{Ca}$ and $\mathrm{HCO}_{3}$ ion pairs, $\mathrm{pH}$ and $\mathrm{EC}$ were 7.86 and $154 \mu \mathrm{S} / \mathrm{cm}$, respectively. For CERDERA, the EC was $619 \mu \mathrm{S} / \mathrm{cm}$ and was dominated by the anion and cation of $\mathrm{Na}$ and $\mathrm{HCO}_{3}$. The ionic difference is because Çermik Stream water is physically and chemically affected by geothermal well water.

According to the IAH (1979) classification, the ŞGF thermal waters are $\mathrm{Na}-\mathrm{HCO}_{3}-\mathrm{Cl}$ type, while the cold springs and surface waters are generally $\mathrm{Ca}-\mathrm{HCO}_{3}$ type (Table 3 ). $\mathrm{Ca}$ and $\mathrm{HCO}_{3}$ ions are dominant in the rainy season in CERDERY, whereas $\mathrm{Mg}$ and $\mathrm{Na}$ ions are accompanied by $\mathrm{Ca}$ ions in the periods when the effect of precipitation is reduced. The Piper diagram (1944) was used to classify the geothermal, cold spring, and surface waters and to determine hydrogeochemical processes, and the Schoeller diagram (1962) was used to compare the chemical content of the waters. The thermal water in the ŞGF has higher alkali elements $(\mathrm{Na}+\mathrm{K})$ than earth alkali elements $(\mathrm{Ca}+\mathrm{Mg})$. The waters with low $\mathrm{SO}_{4}$ have similar $\mathrm{Cl}$ and $\mathrm{HCO}_{3}$ ion concentrations. The thermal water and CDMS have similar chemical compositions. The cold springs and surface waters have more earth alkali elements $(\mathrm{Ca}+\mathrm{Mg})$ than alkali elements $(\mathrm{Na}+\mathrm{K})$, with more

Table 1 Coordinates and elevations of sampling points in the study area

\begin{tabular}{llll}
\hline Sample name & Definitions & $\begin{array}{l}\text { Coordinates (UTM 37 T } \\
\text { WGS84) }\end{array}$ & Elevation (m) \\
\hline ILICAS & Thermal well water & $0282740-4586153$ & 1495 \\
CDMS & Mineral water & $0281351-4573470$ & 1145 \\
GMS & Mineral water & $0283639-4586548$ & 1600 \\
SSSK & Cold spring water & $0282628-4588250$ & 1550 \\
GSK & Cold spring water & $0283484-4586187$ & 1712 \\
CERDERY & Surface water & $0281280-4586418$ & 1490 \\
CERDERA & Surface water & $0282940-4585958$ & 1496 \\
\hline
\end{tabular}




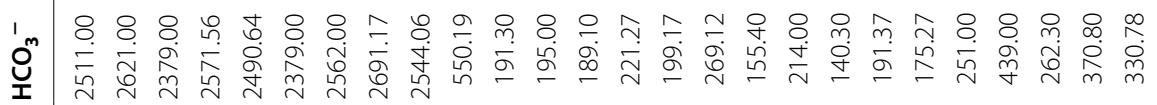

1

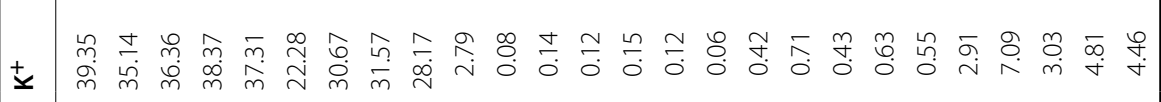

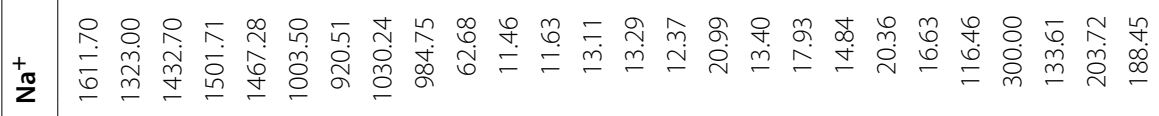

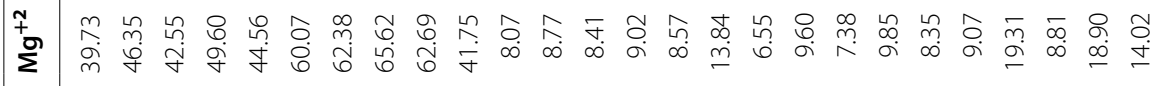

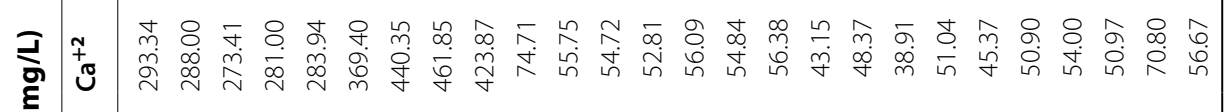

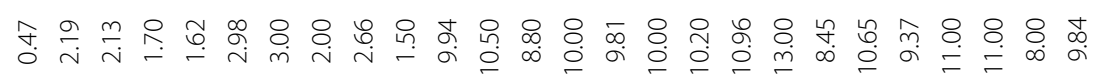

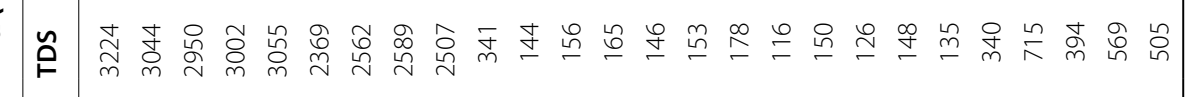

है

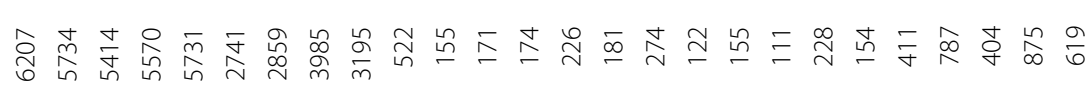

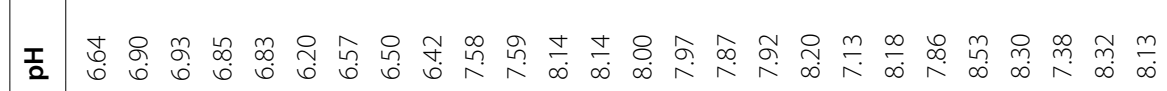

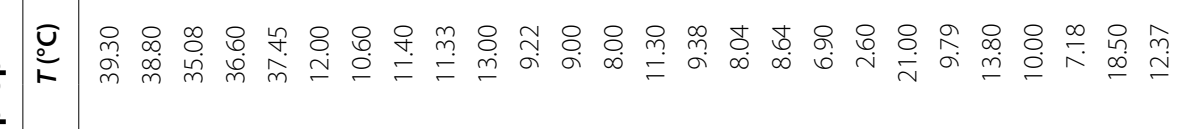

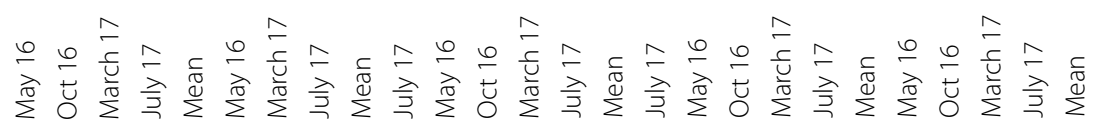




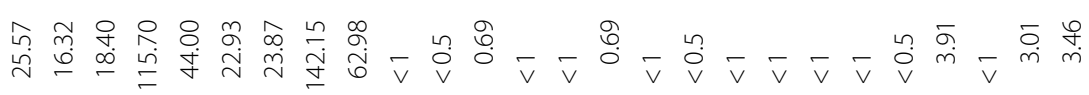

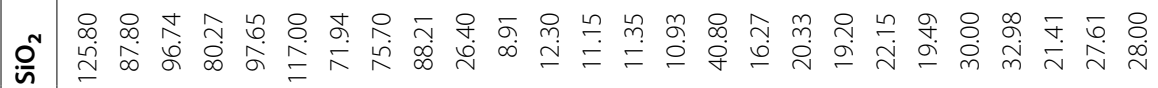

茬

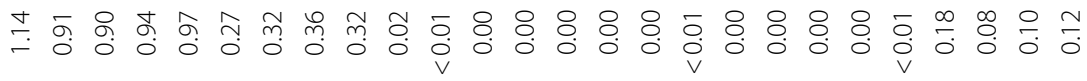

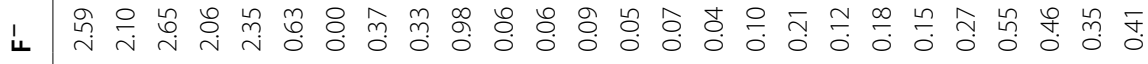

宁

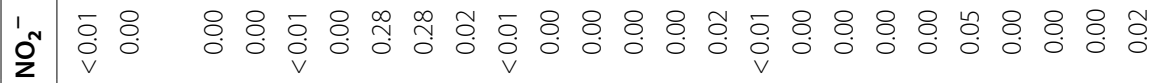

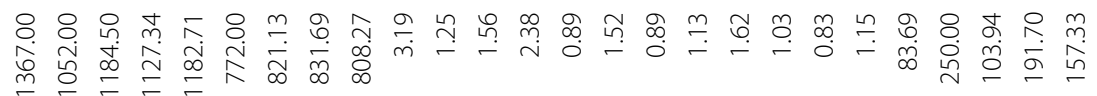
$--\ldots$

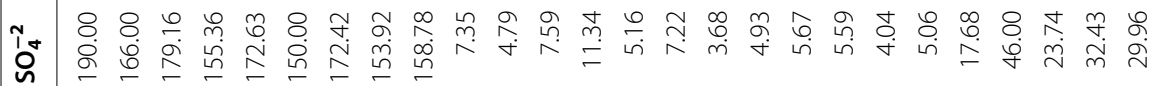

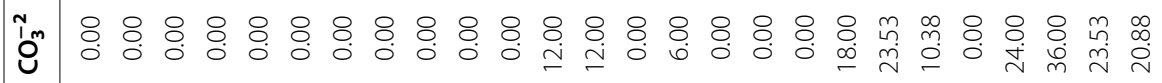

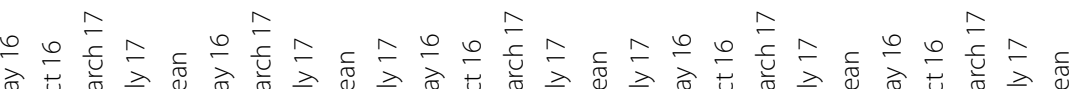

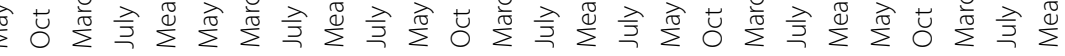


Table 3 Classification of the waters in Şavşat Geothermal Field according to IAH (1979)

\begin{tabular}{|c|c|c|c|}
\hline Sample name & Definitions & Sampling date & Water type \\
\hline \multirow[t]{4}{*}{ ILICAS } & \multirow[t]{4}{*}{ Thermal well water } & May 16 & $\mathrm{Na}-\mathrm{HCO}_{3}-\mathrm{Cl}$ \\
\hline & & October 16 & $\mathrm{Na}-\mathrm{HCO}_{3}-\mathrm{Cl}$ \\
\hline & & March 17 & $\mathrm{Na}-\mathrm{HCO}_{3}-\mathrm{Cl}$ \\
\hline & & July 17 & $\mathrm{Na}-\mathrm{HCO}_{3}-\mathrm{Cl}$ \\
\hline \multirow[t]{3}{*}{ CDMS } & \multirow[t]{3}{*}{ Mineral water } & May 16 & $\mathrm{Na}-\mathrm{Ca}-\mathrm{HCO}_{3}-\mathrm{Cl}$ \\
\hline & & March 17 & $\mathrm{Na}-\mathrm{Ca}-\mathrm{HCO}_{3}-\mathrm{Cl}$ \\
\hline & & July 17 & $\mathrm{Na}-\mathrm{Ca}-\mathrm{HCO}_{3}-\mathrm{Cl}$ \\
\hline GMS & Mineral water & July 17 & $\mathrm{Ca}-\mathrm{Mg}-\mathrm{Na}-\mathrm{HCO}_{3}$ \\
\hline \multirow[t]{4}{*}{ ŞSSK } & \multirow[t]{4}{*}{ Spring water } & May 16 & $\mathrm{Ca}-\mathrm{HCO}_{3}$ \\
\hline & & October 16 & $\mathrm{Ca}-\mathrm{HCO}_{3}$ \\
\hline & & March 17 & $\mathrm{Ca}-\mathrm{HCO}_{3}$ \\
\hline & & July 17 & $\mathrm{Ca}-\mathrm{HCO}_{3}$ \\
\hline GSK & Spring water & July 17 & $\mathrm{Ca}-\mathrm{Mg}-\mathrm{HCO}_{3}$ \\
\hline \multirow[t]{4}{*}{ CERDERY } & \multirow[t]{4}{*}{ Surface water } & May 16 & $\mathrm{Ca}-\mathrm{HCO}_{3}$ \\
\hline & & October 16 & $\mathrm{Ca}-\mathrm{Mg}-\mathrm{Na}-\mathrm{HCO}_{3}$ \\
\hline & & March 17 & $\mathrm{Ca}-\mathrm{Na}-\mathrm{HCO}_{3}$ \\
\hline & & July 17 & $\mathrm{Ca}-\mathrm{Na}-\mathrm{HCO}_{3}$ \\
\hline \multirow[t]{4}{*}{ CERDERA } & \multirow[t]{4}{*}{ Surface water } & May 16 & $\mathrm{Na}-\mathrm{Ca}-\mathrm{HCO}_{3}-\mathrm{Cl}$ \\
\hline & & October 16 & $\mathrm{Na}-\mathrm{HCO}_{3}-\mathrm{Cl}$ \\
\hline & & March 17 & $\mathrm{Na}-\mathrm{Ca}-\mathrm{HCO}_{3}$ \\
\hline & & July 17 & $\mathrm{Na}-\mathrm{Ca}-\mathrm{HCO}_{3}$ \\
\hline
\end{tabular}

weak acid compounds $\left(\mathrm{CO}_{3}+\mathrm{HCO}_{3}\right)$ than strong acid compounds $\left(\mathrm{Cl}+\mathrm{SO}_{4}\right)$ (Fig. 7). Thermal waters have compositions similar to those of mineral waters, although hot water has higher ion concentrations (Fig. 8).

The processes that affect the major ion concentrations of thermal water in the ŞGF were evaluated according to Hounslow (1995). The ratios of $\mathrm{HCO}_{3} / \mathrm{SiO}_{2}$ and $\mathrm{Mg} /$ $(\mathrm{Ca}+\mathrm{Mg})$ are 67.4 and 0.22 , respectively. In addition, the ratio of $\mathrm{SiO}_{2} /(\mathrm{Na}+\mathrm{K}-\mathrm{Cl})$ is 0.018 , and the ratio of $(\mathrm{Na}+\mathrm{K}-\mathrm{Cl}) /(\mathrm{Na}+\mathrm{K}-\mathrm{Cl}+\mathrm{Ca})$ is 0.72 . According to these values, carbonate decomposition, cation exchange, and plagioclase decomposition processes control the major ion concentrations of the thermal water.

\section{Mineral saturation}

The change in the mineral saturation states in water helps to determine the stages of hydrochemical evolution and is important in terms of which chemical reactions have effects on water chemistry (Drever 1997; Langmuir 1997). Especially for thermal and mineral waters, the early estimation of scaling and corrosion properties is very important in terms of preventing residue that may occur during the use of the waters. Additionally, chemical reactions occurring in groundwater provide an opportunity to interpret the hydrochemical environment.

Primary and secondary minerals were microscopically determined in the rocks outcropping in the study area, and the saturation of all waters sampled in terms of these minerals was investigated (Table 4, Fig. 9). The primary minerals in the volcanic rocks exposed in the study area are silicate minerals such as plagioclase, K-feldspar, 


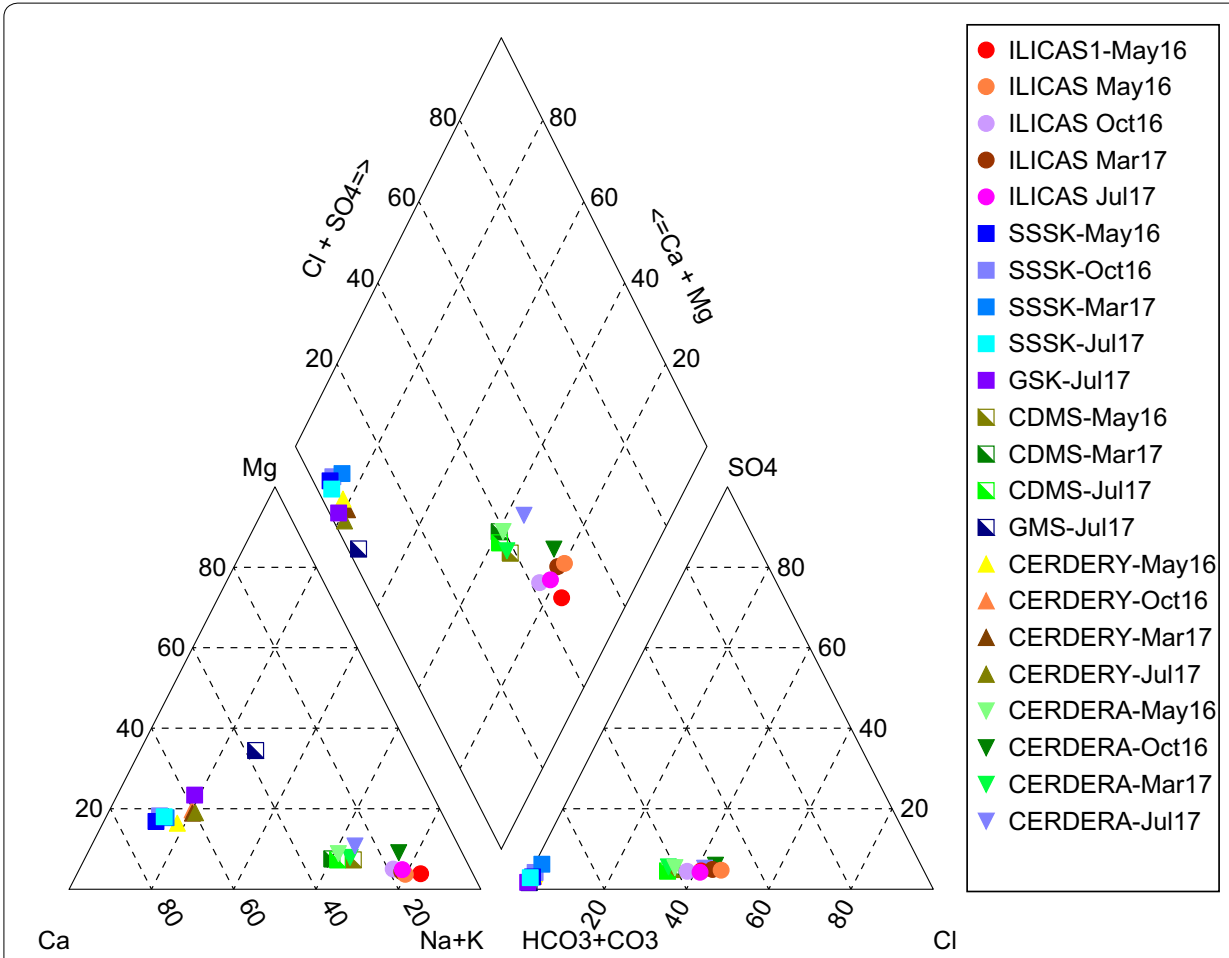

Fig. 7 Piper diagram for thermal and cold waters in the study area

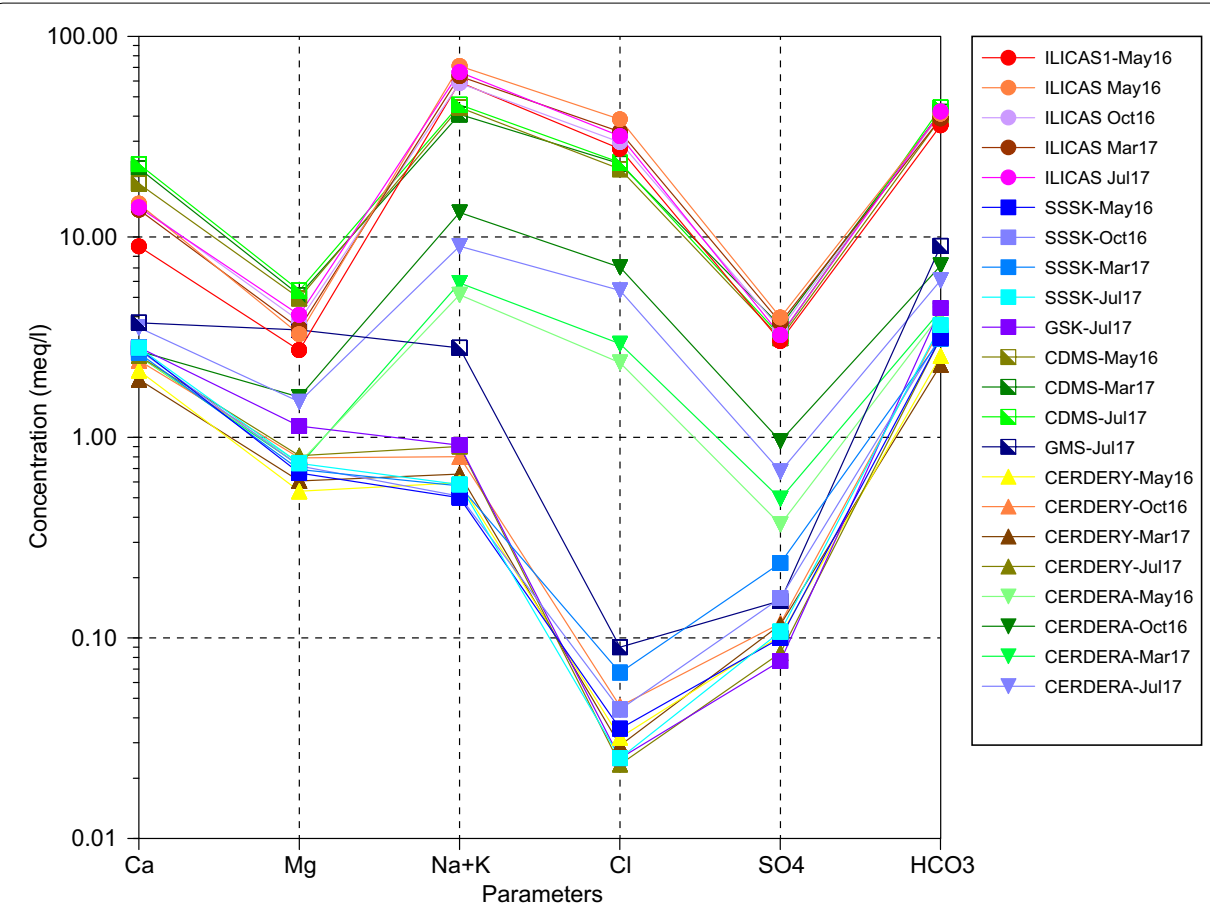

Fig. 8 Schoeller diagram indicating ionic concentrations of waters in the study area 
Table 4 Mineral saturation indices (SI) for thermal waters in the Şavşat Geothermal Field

\begin{tabular}{|c|c|c|c|c|c|}
\hline Minerals & Formula & ILICAS & CDMS & SSSK & CERDERY \\
\hline Albite & $\mathrm{NaAlSi}_{3} \mathrm{O}_{8}$ & 1.75 & 1.48 & -3.01 & -1.90 \\
\hline Anhydrite & $\mathrm{CaSO}_{4}$ & -1.47 & -1.47 & -3.15 & -3.22 \\
\hline Aragonite & $\mathrm{CaCO}_{3}$ & 0.69 & 0.00 & -0.20 & -0.07 \\
\hline Barite & $\mathrm{BaSO}_{4}$ & 0.41 & 0.82 & - & -1.41 \\
\hline Ca-montmorillonite & $\mathrm{Ca} 0.165 \mathrm{Al}_{2} 33 \mathrm{Si}_{3} 67 \mathrm{O}_{10}(\mathrm{OH})_{2}$ & 6.40 & 7.10 & 1.91 & 2.78 \\
\hline Calcite & $\mathrm{CaCO}_{3}$ & 0.83 & 0.16 & -0.04 & 0.09 \\
\hline Celestine & $\mathrm{SrSO}_{4}$ & -1.94 & -3.49 & -4.17 & -4.07 \\
\hline Dolomite & $\mathrm{CaMg}\left(\mathrm{CO}_{3}\right)_{2}$ & 1.28 & -0.32 & -0.82 & -0.54 \\
\hline Fluorite & $\mathrm{CaF}_{2}$ & -0.23 & -0.94 & -3.27 & -2.91 \\
\hline Gypsum & $\mathrm{CaSO}_{4}: 2 \mathrm{H}_{2} \mathrm{O}$ & -1.33 & -1.21 & -2.90 & -2.96 \\
\hline Goethite & $\mathrm{FeOOH}$ & 6.24 & 3.38 & 7.54 & 8.10 \\
\hline Halite & $\mathrm{NaCl}$ & -4.40 & -4.77 & -9.37 & -9.33 \\
\hline Hematite & $\mathrm{Fe}_{2} \mathrm{O}_{3}$ & 14.55 & 8.70 & 17.01 & 18.13 \\
\hline Illite & $\mathrm{K} 0.6 \mathrm{Mg} 0.25 \mathrm{Al}_{2} 3 \mathrm{Si}_{3} 5 \mathrm{O}_{10}(\mathrm{OH})_{2}$ & 5.49 & 5.54 & 0.12 & 1.63 \\
\hline K-feldspar & $\mathrm{KAISi}_{3} \mathrm{O}_{8}$ & 2.31 & 2.33 & -2.62 & -0.85 \\
\hline K-mica & $\mathrm{KAl}_{3} \mathrm{Si}_{3} \mathrm{O}_{10}(\mathrm{OH})_{2}$ & 12.28 & 12.20 & 5.95 & 7.54 \\
\hline Kaolinite & $\mathrm{Al}_{2} \mathrm{Si}_{2} \mathrm{O}_{5}(\mathrm{OH})_{4}$ & 6.72 & 7.41 & 3.93 & 4.30 \\
\hline Amorphous silica & $\mathrm{SiO}_{2}$ & 0.78 & 1.15 & 0.07 & 0.34 \\
\hline Rhodocrosite & $\mathrm{MnCO}_{3}$ & -1.32 & -2.51 & - & - \\
\hline Siderite & $\mathrm{FeCO}_{3}$ & -0.60 & -1.37 & -0.88 & -1.04 \\
\hline Talc & $\mathrm{Mg}_{3} \mathrm{Si}_{4} \mathrm{O}_{10}(\mathrm{OH})_{2}$ & -1.84 & -7.00 & -5.26 & -2.55 \\
\hline Witherite & $\mathrm{BaCO}_{3}$ & -2.63 & -3.23 & - & -3.80 \\
\hline
\end{tabular}

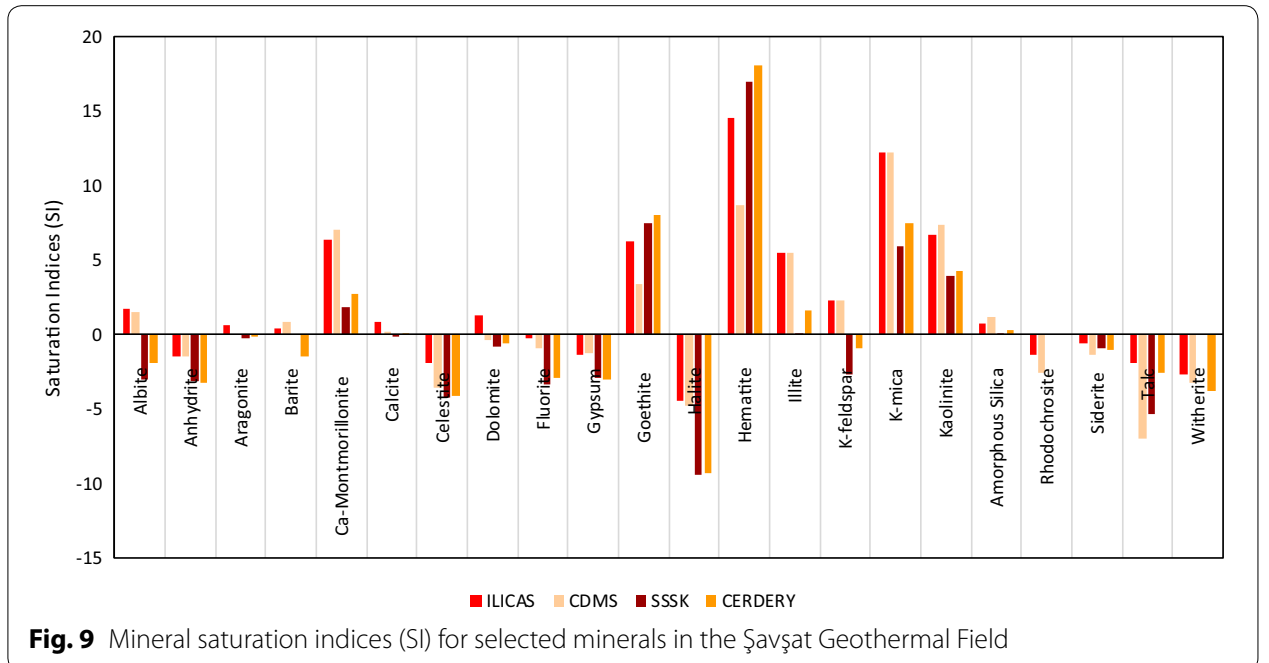

augite, hornblende, and quartz, while secondary minerals are calcite, quartz, and chlorite. The SI was calculated for minerals selected from the limestone, sandstone, gypsum lenses, and opaque minerals forming sedimentary units using the AquaChem chemical equilibrium software. Negative SI values in Table 4 indicate an undersaturated solution, and positive values indicate an oversaturated solution. SI values that are meaningless (e.g., -40 ) were ignored. When the SI values were examined, all hot and cold waters were not saturated with respect to sulfate minerals such as anhydrite 


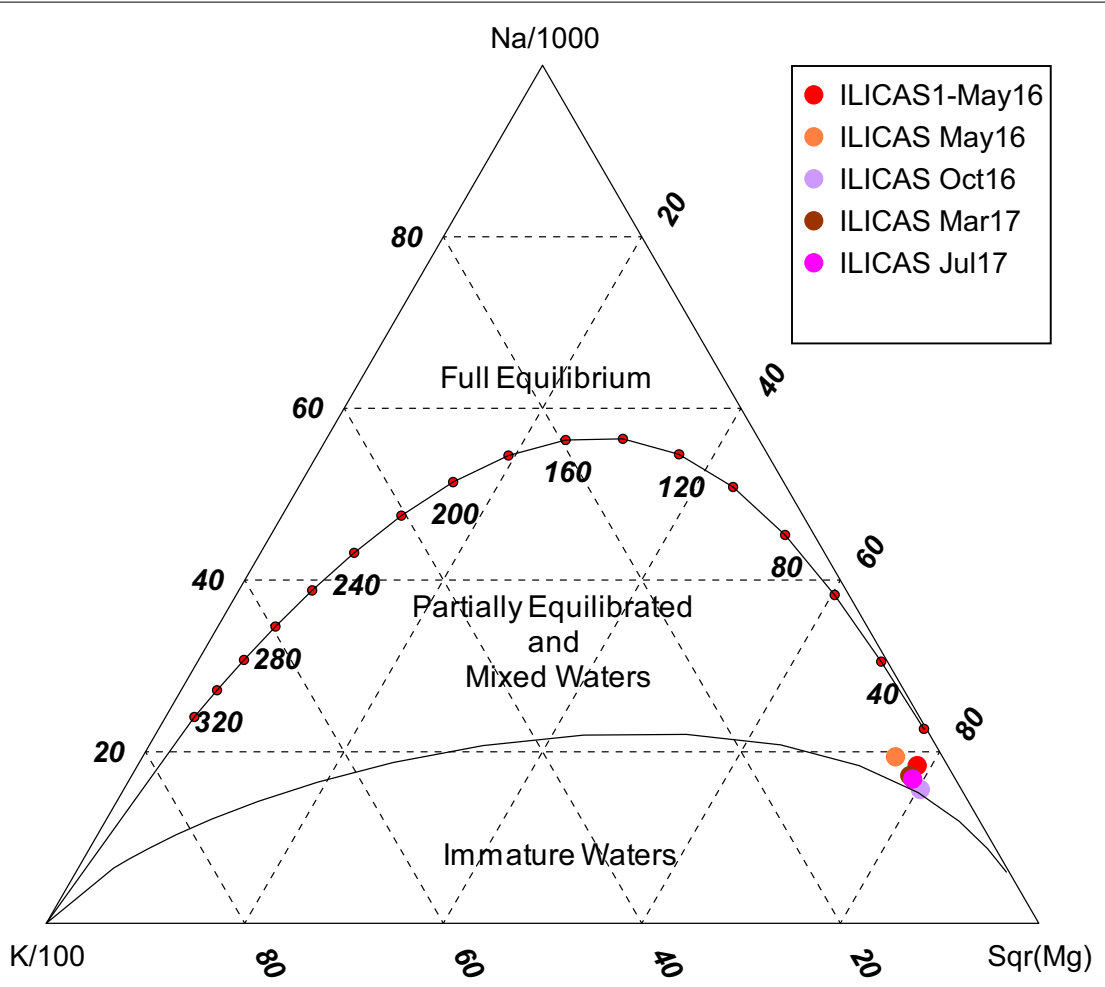

Fig. $10 \mathrm{Na}-\mathrm{K}-\mathrm{Mg}$ ternary diagram (Giggenbach 1988) for the thermal waters of the Şavşat Geothermal Field

and gypsum and minerals such as fluorite and halite. The geothermal water (ILICAS) and Ciritdüzü mineral water (CDMS) were saturated with respect to aragonite, calcite, and dolomite, while the cold spring waters were undersaturated in these minerals. The silicate mineral K-feldspar was oversaturated in the hot water and CDMS but undersaturated in the cold waters. Both thermal water and mineral water showed slight oversaturation in amorphous silica. All waters were oversaturated with respect to K-mica, clay minerals of kaolinite and illite, and iron minerals of goethite and hematite, but they were undersaturated with respect to talc.

\section{Geothermometers}

The estimation of the aquifer temperature in geothermal systems is very important in terms of the appropriate use of thermal and mineral waters. With the aim of defining the reservoir rock temperature in geothermal areas, geothermometry methods were developed based on chemical (Fournier 1977; Arnorsson et al. 1983) and isotopic (Lloyd 1968; Mizutani and Rafter 1969) analyses of springs and wells.

Another method used is the $\mathrm{Na}-\mathrm{K}-\mathrm{Mg}$ combined geothermometer developed by Giggenbach (1988) for estimating the aquifer temperature of thermal waters and determining the maturity of rocks in contact with the water (Fig. 10). This geothermometer may be used to test the validity of cation geothermometers and rapidly interpret the reservoir rock temperatures of thermal waters. On the Giggenbach (1988) diagram, the thermal water from the Şavşat Geothermal Field is plotted in "the 
Table 5 Estimated reservoir temperatures $\left({ }^{\circ} \mathrm{C}\right)$ for the Şavşat thermal waters using silica geothermometers $\left(\mathrm{SiO}_{2}=125.8 \mathrm{mg} / \mathrm{L}\right)$

\begin{tabular}{|c|c|c|c|}
\hline Geothermometers & Equations & References & $\begin{array}{l}\text { Calculated } \\
\text { temp. }\end{array}$ \\
\hline $\mathrm{SiO}_{2}$ (众 Cristobalite) & $t=1000 /\left(4.78-\log \mathrm{SiO}_{2}\right)-273.15$ & Fournier (1977) & 100 \\
\hline $\mathrm{SiO}_{2}$ (Quartz) & $t=1309 /\left(5.19-\log \mathrm{SiO}_{2}\right)-273.15$ & Fournier (1977) & 150 \\
\hline $\mathrm{SiO}_{2}$ (Quartz steam loss) & $t=1522 /\left(5.75-\log \mathrm{SiO}_{2}\right)-273.15$ & Fournier (1977) & 144 \\
\hline $\mathrm{SiO}_{2}$ (Quartz steam loss) & $t=1264 /\left(5.31-\log S_{i} O_{2}\right)-273.15$ & Arnorsson et al. (1983) & 121 \\
\hline $\mathrm{SiO}_{2}$ (Quartz steam loss) & $t=1164 /\left(4.9-\log \mathrm{SiO}_{2}\right)-273.15$ & Arnorsson et al. (1983) & 143 \\
\hline $\mathrm{SiO}_{2}$ (Chalcedony) & $t=1032 /\left(4.69-\log \mathrm{SiO}_{2}\right)-273.15$ & Fournier (1977) & 125 \\
\hline $\mathrm{SiO}_{2}$ (Chalcedony) & $t=1112 /\left(4.91-\log \mathrm{SiO}_{2}\right)-273.15$ & Arnorsson et al. (1983) & 122 \\
\hline
\end{tabular}

partly matured water" area. Generally, $\mathrm{Na} / \mathrm{K}$ geothermometers provide confirmatory results at temperatures between 180 and $350{ }^{\circ} \mathrm{C}$ and may provide erroneous results below $120{ }^{\circ} \mathrm{C}$. At these low temperatures, $\mathrm{Na}$ and $\mathrm{K}$ ions are affected by clay minerals and do not control ion exchange reactions. Thus, the values above the actual aquifer temperatures were obtained by geothermometer calculations (Gemici 1999), and silica geothermometers were used to calculate the reservoir temperatures in the studied geothermal field. Calculated reservoir temperatures close to or below the discharge temperature of the geothermal waters were ignored. The quartz geothermometer gave reservoir temperatures ranging from 121 to $150{ }^{\circ} \mathrm{C}$ for the ŞGF, while the chalcedony geothermometer yielded $122-125{ }^{\circ} \mathrm{C}$ reservoir temperatures (Table 5). At low temperatures, the dissolved silica concentration controls chalcedony; however, the quartz geothermometer provides better results at higher temperatures. Therefore, the estimated reservoir temperature of the ŞGF was $120-125^{\circ} \mathrm{C}$, according to the chalcedony geothermometer (Table 5).

The reservoir temperatures calculated by the $\mathrm{SO}_{4}-\mathrm{H}_{2} \mathrm{O}$ oxygen isotope geothermometers proposed by Lloyd (1968) and Mizutani and Rafter (1969) were $60-70{ }^{\circ} \mathrm{C}$ for the ŞGF, which were lower than those calculated by the silica geothermometers. The reason for this is the change in $\delta^{18} \mathrm{O}$ values due to the mixing of sulfate-poor shallow groundwater with geothermal waters.

\section{Enthalpy-silica mixture model}

The hot fluid component of the geothermal system mixes with cold groundwater at different depths and rates while traveling to the surface. The Şavşat water is determined to be peripheral water based on the $\mathrm{Cl}-\mathrm{SO}_{4}-\mathrm{HCO}_{3}$ diagram (Fig. 11). A variety of mixing models have been developed to determine the reservoir temperature and mixing ratio in geothermal systems (Fournier and Truesdell 1974; Şahinci 1991). The most commonly used models are the silica-enthalpy and enthalpy-chloride mixing models. The silicaenthalpy mixing model diagram may be used to estimate reservoir temperatures in situations with no loss of steam and temperature before mixing and loss of steam before mixing (adiabatic cooling). This mixing model is used to determine the reservoir temperature of geothermal fields and evaluate the effects of the mixing processes (Truesdell and Fournier 1977). Figure 12 shows the silica-enthalpy mixing model based on quartz solubilities. In this model, two end member fluids are presented: a cold water sample 


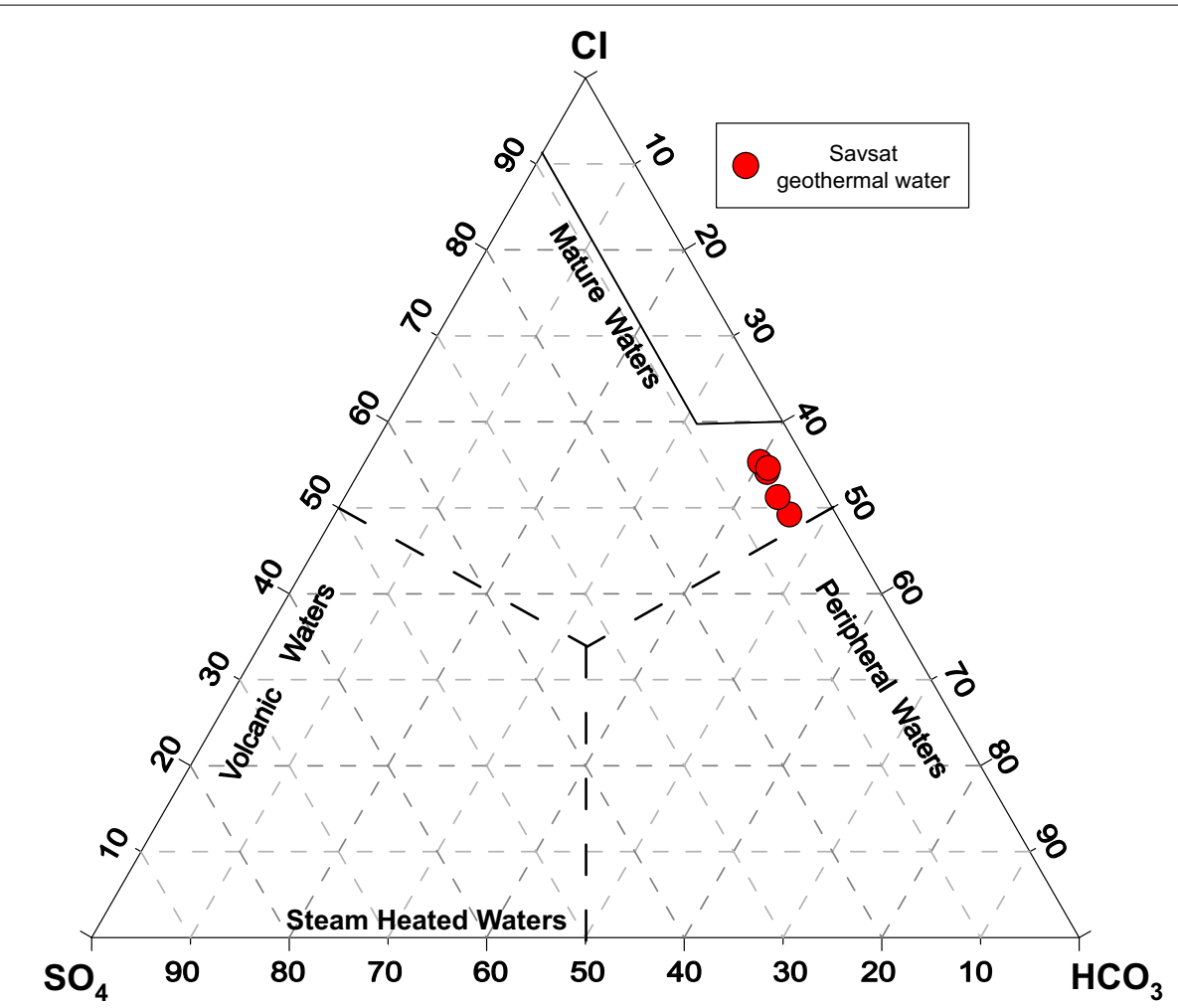

Fig. $11 \mathrm{Cl}-\mathrm{SO}_{4}-\mathrm{HCO}_{3}$ ternary diagram for geothermal waters

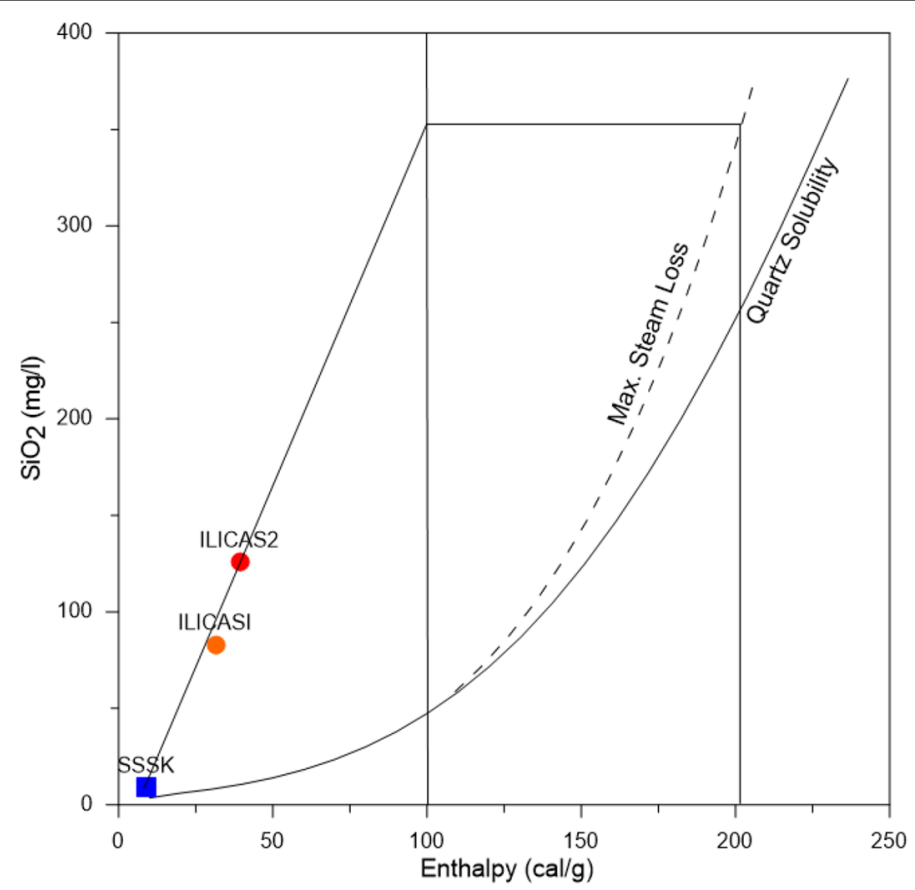

Fig. 12 Silica-enthalpy mixture model for Şavşat Geothermal Water 
(SSSK sample; temperature: $9.38^{\circ} \mathrm{C}$ ) as one endmember and the thermal waters (ILICAS sample; temperature: $37.45^{\circ} \mathrm{C}$ ) as the other endmember. In this model, thermal waters form as the result of the mixing of thermal water with cold water, assuming maximum steam loss. The intersection point with the solubility curve for quartz (maximum steam loss) yields a reservoir temperature of $195{ }^{\circ} \mathrm{C}$ for the ŞGF thermal water. The mixing rate with cold groundwater is calculated to be $70 \%$ for the ŞGF. This value is higher than the reservoir temperature calculated by the silica geothermometers. The ŞGF thermal waters may lose some heat due to possible mixing with cold water along the fracture zones during its ascent to the surface. Therefore, the silica geothermometer appears to reflect reservoir temperatures more accurately than the other geothermometers.

\section{Isotope studies}

Oxygen-18 and deuterium stable isotopes were employed to determine the possible recharge areas of water, and tritium was employed to calculate the relative age of the waters and their residence times. Carbon-13 was used to determine the origin of carbon as well as oxygen-18 and sulfur-34 isotopes in sulfate in the waters (Table 6).

$\delta^{18} \mathrm{O}$ and $\delta^{2} \mathrm{H}$ relationships The $\delta^{18} \mathrm{O}$ and $\delta^{2} \mathrm{H}$ values in the waters were evaluated according to the Global Meteoric Water Line (GMWL) (Craig 1961) and the Eastern Black

Table 6 Isotope analysis results for water samples collected in the Şavşat Geothermal Field

\begin{tabular}{|c|c|c|c|c|c|c|c|c|}
\hline Sample name & Date & Definitions & $\begin{array}{l}\delta D \\
\text { V-smow }\end{array}$ & $\begin{array}{l}\delta^{18} \mathrm{O} \\
\text { V-smow }\end{array}$ & $T(\mathrm{TU})$ & $\begin{array}{l}\delta^{13} \mathrm{C} \\
\text { V-PDB }\end{array}$ & $\begin{array}{l}\delta^{34} \mathrm{~S}\left(\mathrm{SO}_{4}\right) \\
\mathrm{VCDT}\end{array}$ & $\begin{array}{l}\delta^{18} \mathrm{O}\left(\mathrm{SO}_{4}\right) \\
\text { v-smow }\end{array}$ \\
\hline \multirow[t]{4}{*}{ ILICAS } & May 16 & \multirow{4}{*}{$\begin{array}{l}\text { Geothermal } \\
\text { water }\end{array}$} & -100.38 & -13.03 & 0.74 & \multirow[t]{2}{*}{4.31} & \multirow[t]{2}{*}{10.6} & \multirow[t]{2}{*}{9.6} \\
\hline & October 16 & & -97.99 & -12.84 & 2.49 & & & \\
\hline & March 17 & & -97.14 & -13.24 & 0.90 & \multirow[t]{2}{*}{7.70} & \multirow[t]{2}{*}{10.9} & \multirow[t]{2}{*}{11.6} \\
\hline & July 17 & & -100.36 & -13.03 & 1.11 & & & \\
\hline \multirow[t]{3}{*}{ CDMS } & May 16 & \multirow[t]{3}{*}{ Mineral water } & -94.81 & -12.4 & 3.59 & \multirow[t]{2}{*}{7.65} & 7.7 & 6.7 \\
\hline & March 17 & & -95.78 & -12.45 & 3.13 & & 6.4 & \multirow[t]{2}{*}{6.0} \\
\hline & July 17 & & -94.88 & -12.48 & 1.95 & 9.55 & & \\
\hline GMS & July 17 & Mineral water & -96.29 & -13.39 & & & & \\
\hline \multirow[t]{4}{*}{ SSSK } & May 16 & \multirow{4}{*}{$\begin{array}{l}\text { Cold spring } \\
\text { water }\end{array}$} & -88.19 & -12.95 & 4.67 & \multirow{2}{*}{-15.4} & \multirow[t]{2}{*}{3.4} & \multirow[t]{2}{*}{0.0} \\
\hline & October 16 & & -89.96 & -12.67 & 4.37 & & & \\
\hline & March 17 & & -86.58 & -12.33 & 4.35 & \multirow[t]{2}{*}{-12.36} & \multirow[t]{2}{*}{4.3} & \multirow[t]{2}{*}{1.7} \\
\hline & July 17 & & -88.38 & -12.59 & 5.70 & & & \\
\hline GSK & July 17 & $\begin{array}{l}\text { Cold spring } \\
\text { water }\end{array}$ & -88.17 & -12.60 & & & & \\
\hline \multirow[t]{4}{*}{ CERDERY } & May 16 & \multirow[t]{4}{*}{ Surface water } & -86.37 & -12.21 & 6.0 & \multirow[t]{2}{*}{-13.82} & \multirow[t]{2}{*}{5.2} & \multirow[t]{2}{*}{-0.7} \\
\hline & October 16 & & -82.32 & -11.78 & 4.29 & & & \\
\hline & March 17 & & -90.60 & -12.50 & 6.35 & -7.79 & 3.5 & 0.8 \\
\hline & July 17 & & -88.15 & -12.40 & 5.25 & & & \\
\hline \multirow[t]{3}{*}{ CERDERA } & October 16 & \multirow[t]{3}{*}{ Surface water } & -85.46 & -11.95 & 5.97 & & & \\
\hline & March 17 & & -90.59 & -12.65 & 3.81 & & & \\
\hline & July 17 & & -88.30 & -12.31 & 4.08 & & & \\
\hline SAVSTKAR & March 17 & Snow & -120.97 & -17.56 & 5.77 & & & \\
\hline
\end{tabular}




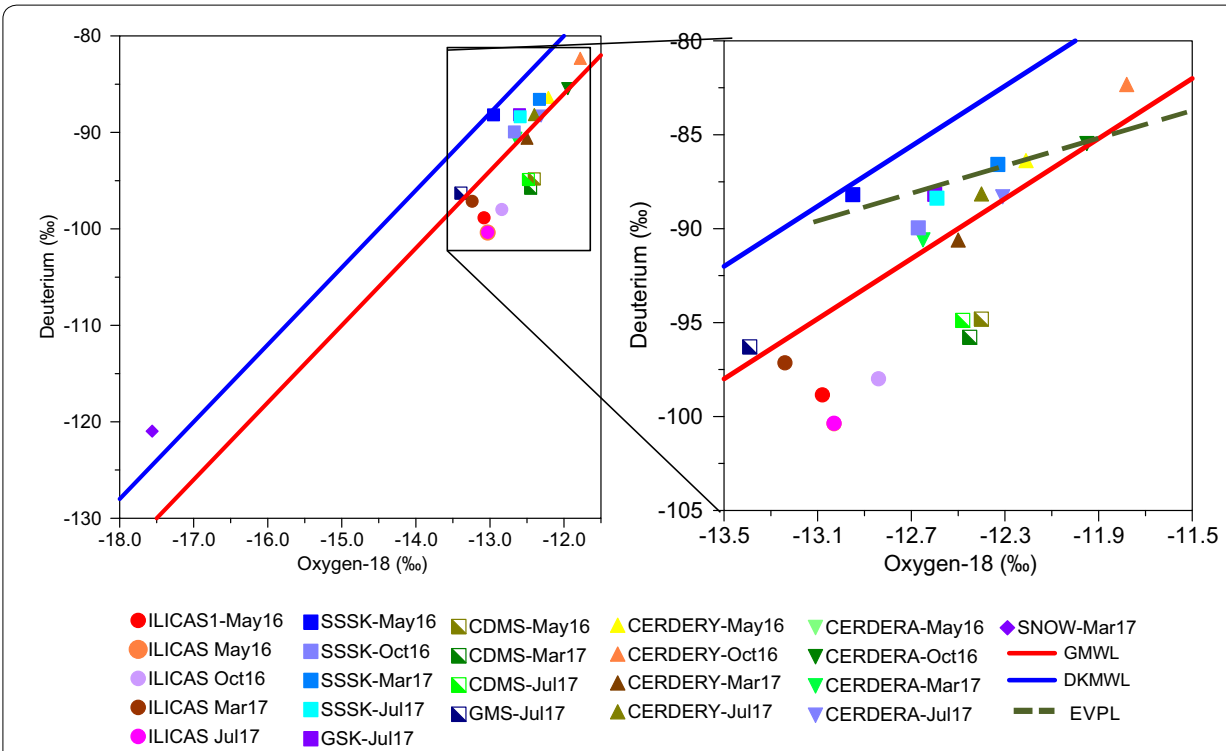

Fig. $13 \delta^{18} \mathrm{O}-\delta^{2} \mathrm{H}$ diagram for waters in the Şavşat Geothermal Field (GMWL Global Meteoric Water Line, DKMWL Eastern Black Sea Meteoric Water Line, EVPL Evaporation Line)

Sea Meteoric Water Line (DKMWL: $\left.\delta^{2} \mathrm{H}=8 \delta^{18} \mathrm{O}+16\right)$ (Ekmekçi and Gültekin 2015). The cold spring and surface waters in the Şavşat field have $\delta^{18} \mathrm{O}$ and $\delta^{2} \mathrm{H}$ values between the GMWL and DKMWL (Fig. 13). The surface waters, spring waters, and geothermal waters plot in different areas. The $\delta^{18} \mathrm{O}$ and $\delta^{2} \mathrm{H}$ values of the snow sample are very different from those of the waters. It is determined that the cold spring and surface waters are recharged by precipitation falling at much lower elevations in the basin compared to the snow. The DKMWL is considered, and the $\delta^{18} \mathrm{O}$ value of the geothermal water shifts to more positive values. This is due to water-rock interactions. The cold spring water is recharged from higher elevations compared to the surface waters. The CDMS has a more positive $\delta^{18} \mathrm{O}$ compared to the values of the surface waters, which indicates a longer duration of interaction with rocks (Fig. 14).

Carbon isotope $\left({ }^{13} \mathrm{C}\right)$ Water filtering underground dissolves $\mathrm{CO}_{2}$ in soil and differentiates it into $\mathrm{HCO}_{3}{ }^{-}$and $\mathrm{CO}_{3}^{-2}$ species. The distribution of dissolved inorganic carbon (DIC) species varies with respect to $\mathrm{pH}$. The variations in DIC and $\delta^{13} \mathrm{C}_{\mathrm{VPDB}}$ also stem from changes in $\mathrm{pH}$ values (Clark and Fritz 1997). The dissolved inorganic carbon $C_{\text {DIC }}$ and $\delta^{13} \mathrm{C}_{\mathrm{VPDB}}$ of groundwater develop as a result of differentiation reactions in aquifers or soil. The $\delta^{13} \mathrm{C}$ isotopes were used to determine the source of carbon in the samples. Analyses were carried out on DIC for $\delta^{13} \mathrm{C}$ (Table 6). The $\delta^{13} \mathrm{C}_{\mathrm{VPDB}}$ value of geothermal water in the study area was determined to be $4.31 \%$ (Table 6). Dissolved inorganic carbon in geothermal water in the study area originates from freshwater carbonates and metamorphic $\mathrm{CO}_{2}$ (Clark and Fritz 1997). For CDMS, the $\delta^{13} \mathrm{C}_{\mathrm{VPDB}}$ value is similar to that of geothermal water, while other cold waters have negative values. The source of carbon in cold waters might be a mixture of freshwater carbonates, groundwater DIC, and soil $\mathrm{CO}_{2}$ (Clark and Fritz 1997). 

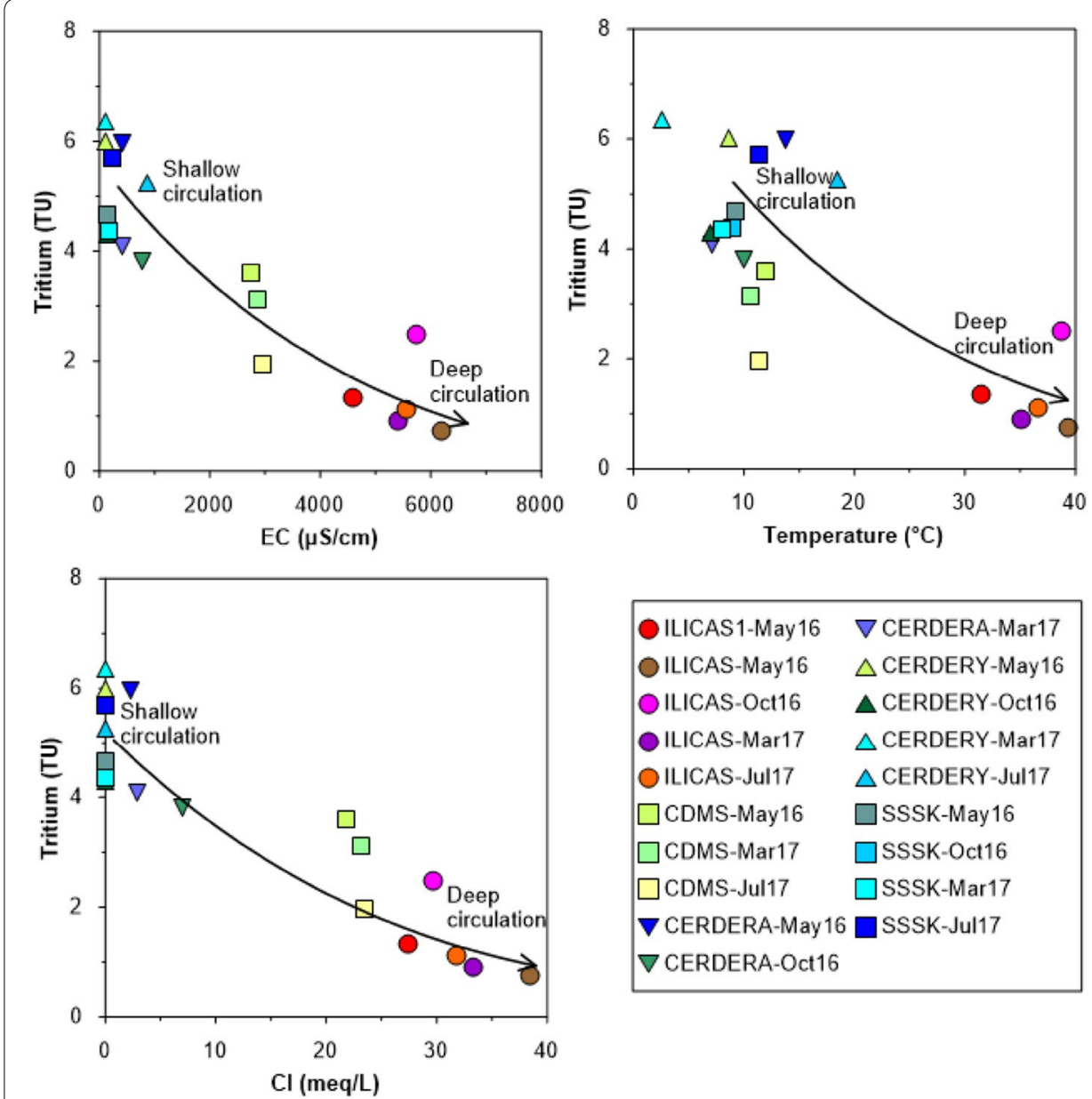

Fig. $14{ }^{3} \mathrm{H}-\mathrm{EC},{ }^{3} \mathrm{H}-\mathrm{Cl}^{-}$, and ${ }^{3} \mathrm{H}-\mathrm{T}\left({ }^{\circ} \mathrm{C}\right)$ relations for waters in the study area

Sulfur isotope $\left({ }^{34} \mathrm{~S}\right)$ Sulfur is found in the crust as dissolved $\mathrm{SO}_{4}^{-2}, \mathrm{SO}_{2}, \mathrm{H}_{2} \mathrm{~S}$, and $\mathrm{SO}_{2}$ species. Organic sulfur is found in humic materials, kerogen, and hydrocarbons. Sulfur-34 is partitioned into many different sulfur compounds. Similarly, the oxygen-18 content of sulfate is an important tool for tracing the sulfur cycle (Clark and Fritz 1997). Values exceeding $-20 \%$ are related to limestones and evaporites. The sulfur-34 ratio in the oxidation of juvenile sulfur is generally between $-5 \%$ and $+5 \%$ (Clark and Fritz 1997). Negative sulfur-34 values occur in diagenetic environments where typically reduced sulfur compounds are present (Krouse 1980). The results of the dissolved $\mathrm{SO}_{4}^{-2}$ ion ${ }^{34} \mathrm{~S}$ isotope analysis for the study area are given in Table 6 . The ${ }^{34} \mathrm{~S}_{\mathrm{CDT}}$ for the geothermal water in the Şavşat Geothermal Field is nearly $10 \%$. In cold waters, the ${ }^{34} \mathrm{~S}_{\mathrm{CDT}}$ value varies from 10 to $3 \%$. According to Krouse (1980), these values show that the sulfur in the geothermal water is derived from volcanic sulfur $\left(\mathrm{SO}_{2}\right)$ and from Cenozoic-age $\mathrm{CaSO}_{4}$, while the sulfur in the cold water is derived from magmatic rocks.

Tritium content The tritium values for the geothermal waters vary from 0.74 to $2.59 \mathrm{TU}$ (Table 6). In mineral water (CDMS), it is nearly $3 \mathrm{TU}$, while in cold spring and surface waters, it varies from 3 to $6 \mathrm{TU}$. The ${ }^{3} \mathrm{H}-\mathrm{EI},{ }^{3} \mathrm{H}-\mathrm{Cl}^{-}$, and ${ }^{3} \mathrm{H}$-temperature cor- 
relations for the water samples are given in Fig. 14. For the geothermal water, mineral water, cold spring water, and surface water, there is a significant negative correlation between the tritium and EC values. Geothermal waters with low tritium values are deeply circulated waters, and the residence time is longer than those of mineral water and cold spring water.

\section{Şavşat (Artvin-Turkey) Geothermal System}

A hydrogeological conceptual model was developed based on geological, hydrochemical, isotopic, and geophysical studies in the study area (Fig. 15). The ŞGF is a liquid-dominated geothermal system. The ŞGF is recharged by infiltrating meteoric waters from the Kabaköy Formation and Bülbülan Formation in the north-northeast. The northern bounding normal fault (F2) and formation boundaries in the northeast (Görizil Hill) might be conduits for water flow. In addition, the NE-SW trending anticline axis is also suitable for the circulation of water. The old thermal springs emerged along the anticline axis and faults.

Drilling and hydrochemical studies indicate that the reservoir rock is volcanogenic sandstone and augite basalt-type volcanic rocks. The porosity of the volcanogenic sandstone (Kabaköy Formation) is $7-10 \%$, and that of the augite basalts is $3-5 \%$. Additionally, volcanogenic sandstones have gained secondary porosity along bedding planes, fractures, and joints in the sandstone and augite basalts. This feature has allowed the unit to gain properties conducive to the storage and circulation of water.

Volcanogenic sandstones with reservoir features widely outcrop in the field. As a result, there is no cap rock fully enclosing the system. However, in areas where the Şavşat Formation displays turbiditic features composed of mudstone-siltstone-sandstone alternations, it forms a cap rock for the geothermal system.

Şavşat thermal waters are controlled by both the regional and the local flow systems, and their chemical and isotopic compositions are attributed to mixing with cold shallow groundwater during their ascent to the surface. The $\delta^{18} \mathrm{O}$ and $\delta^{2} \mathrm{H}$ isotopes of the thermal water show more negative values compared to those of the cold waters and more positive values compared to those of the snow. The $\delta^{18} \mathrm{O}$ values of the thermal water show a slightly positive shift as a result of water-rock isotope exchange. The tritium values of the thermal water are much lower than those of both the cold water and the snow samples. According to these data, geothermal waters form when meteoric water falls as rain into the basin and is transmitted underground, stored in volcanogenic sandstones, and heated up by the geothermal gradient. The heated water reaches the surface by rising along a fracture zone determined in geophysical studies as being oriented parallel to the Çermik Stream valley (Fig. 15). According to the $\delta^{13} \mathrm{C}$ values, the carbon in the thermal water has a metamorphic origin, whereas the carbon in the cold water is derived from the dissolution of Oligocene-Miocene lacustrine carbonate deposits in the region or from $\mathrm{CO}_{2}$ gas that accumulated in pores. The $\delta^{34} \mathrm{~S}$ values show a volcanic origin for sulfur in the geothermal water. CDMS is mineralized cold water outside the hydrological basin of the ILICAS thermal spring; it is very similar to thermal water in terms of its chemical and isotopic compositions. However, due to lower EC and TDS values, it can be defined as a mixing water. 


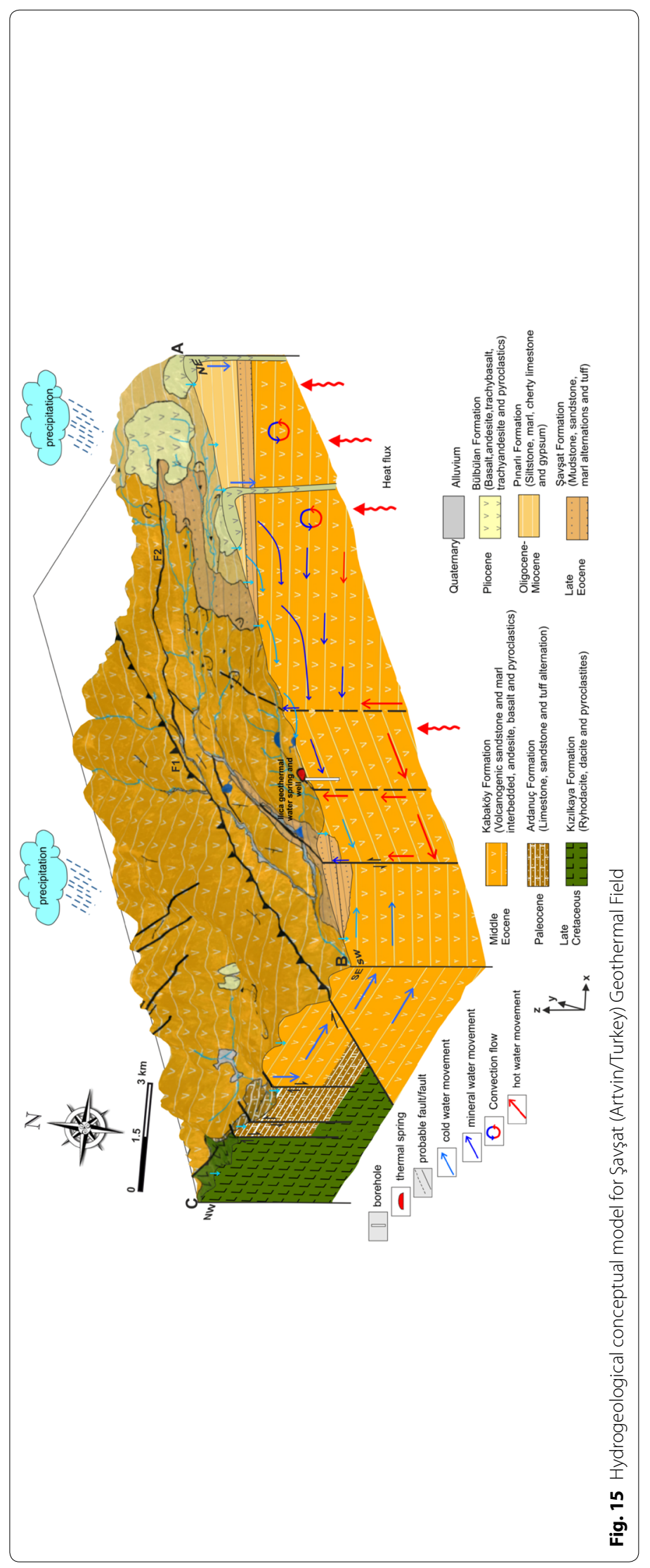


According to Türkecan (2017), volcanic rocks outcropping in wide areas in Kars and Ardahan are late Pliocene-early Pleistocene (Duru and Keskin 2014) andesite, dacite, and rhyolite. Andesitic and dacitic lava flows form ridges and domes, but dacitic rocks also occasionally occur as lava flows. These volcanic rocks, named the Ardahan andesite (Karaköse et al. 1994), Ulgartepe andesite (Karaköse et al. 1994), or Dumanlıdağ volcanic rocks (Aktimur et al. 1982), have been dated at 1.6-2.7 million years with a variety of methods (Innocenti et al. 1982; Karaköse et al. 1994). The volcanic rocks represented by trachyandesite, trachybasalt, hornblende andesite, and pyroclastics outcrop as ridges and domes in the Şavşat Geothermal Field and can be correlated with the Pliocene-Pleistocene volcanic rocks based upon their petrographic properties (Fig. 15). The young volcanic activity in the area caused an increase in the geothermal gradient. Therefore, the heat source for the geothermal system is considered to be this young volcanic activity. The $\delta^{34} S$ values of the geothermal waters also support this idea.

The reservoir temperature for the SGF was calculated as $100-150{ }^{\circ} \mathrm{C}$ by the silica geothermometer. According to the calculated reservoir temperature, the field is classified as a low-moderate enthalpy field (Muffler and Cataldi 1978; Benderitter and Cormy 1990; Hochstein 1990; Haenel et al. 1988). Magmatic activity feeding young volcanic rocks in the field was interpreted as a source of heat. Deeply heated water associated with this magmatic activity was driven upward along the faults and fractures.

\section{Conclusions}

The Şavşat (Artvin-Turkey) Geothermal Field contains outcrops of volcanic, volcano sedimentary, and sedimentary units formed during the late Cretaceous to the PliocenePleistocene time periods. The artesian water recharging from a $120-\mathrm{m}$-depth borehole in the ŞGF has a temperature of $38{ }^{\circ} \mathrm{C}$, an EC value of $5731 \mu \mathrm{S} / \mathrm{cm}$, and a $\mathrm{pH}$ of 6.83 . The $\mathrm{Na}-\mathrm{HCO}_{3}-\mathrm{Cl}$-type geothermal water is oversaturated with respect to aragonite, calcite, dolomite, amorphous silica, K-mica, kaolinite, talc, and hematite minerals and undersaturated with respect to minerals such as gypsum, anhydrite, halite, fluorite, rhodochrosite, and siderite. The reservoir temperature is estimated at $100-150{ }^{\circ} \mathrm{C}$ using a silica geothermometer. The mixing rate of geothermal waters with cold groundwater is calculated to be $70 \%$. In deeply circulated geothermal waters, carbon is derived from metamorphic $\mathrm{CO}_{2}$, and sulfur is of volcanic origin. The cold waters indicate an origin of groundwater DIC.

The reservoir rocks of the ŞGF are volcanogenic sandstone and late Cretaceous volcanic rocks of andesite, basalt, and pyroclastics. The heat source is the geothermal gradient arising from Quaternary volcanic activity. The late Eocene turbiditic unit comprising mudstone, siltstone, and marl forms a partial cap rock. Geophysical studies in the field identified a potential thermal water reservoir at elevations of 1250-1350 m. At borehole of at least $300 \mathrm{~m}$ may intersect an area of fluids with more pressure and higher temperatures than the present well and spring water. 


\section{Abbreviations}

ŞGF: Şavşat Geothermal Field; T: temperature; EC: electrical conductivity; TDS: total dissolved substance; DO: dissolved oxygen; GMWL: Global Meteoric Water Line; DKMWL: Eastern Black Sea Meteoric Water Line; DIC: dissolved inorganic carbon.

\section{Authors' contributions}

FG conducted hydrogeological studies and contributed significantly to the writing of the paper. EHT conducted hydrogeochemical studies. AEB conducted and commented on geophysical studies. MZK conducted geological studies and described the rocks type. AFE participated in hydrogeological studies. BMS participated in geological mapping studies and sampling. All authors read and approved the final manuscript.

\section{Author details}

${ }^{1}$ Geological Engineering Department, Karadeniz Technical University, Trabzon, Turkey. ${ }^{2}$ Geophysical Engineering Department, Karadeniz Technical University, Trabzon, Turkey.

\section{Acknowledgements}

This study was supported by The Scientific and Technical Research Council of Turkey (TUBITAK Project Number: 115Y142). The authors thank TUBITAK for their financial support. The authors also thank Prof. Dr. Necati TÜYSÜZ from the KTÜ for his help with the English of the final text. We wish to thank the Executive Editor Prof. Dr. Ernst Huenges, three anonymous reviewers.

Competing interests

The authors declare that they have no competing interests.

\section{Availability of data and materials}

Not applicable

\section{Funding}

All of this study was prepared by data of TÜBITAK funded project numbered $115 Y 142$.

\section{Publisher's Note}

Springer Nature remains neutral with regard to jurisdictional claims in published maps and institutional affiliations.

Received: 26 November 2018 Accepted: 25 April 2019

Published online: 06 May 2019

\section{References}

Abiye TA, Haile T. Geophysical exploration of the Boku geothermal area, Central Ethiopian Rift. Geothermics. 2008;37:586-96.

Aizawa T. Application manual of geophysical methods to engineering and environmental problems edited by the society of exploration geophysicists of Japan. Houten: EAGE Publishers; 2014.

Akkuş I, Akıllı H, Ceyhan S, Dilemre A, Tekin Z. Türkiye Jeotermal Kaynakları Envanteri. Maden Teknik Arama Genel Müdürlüğü Envanter Serisi-201, Ankara; 2005. (in Turkish).

Aktimur HT, Tekirli ME, Ateş S, Teoman MŞ, Yurdakul ME, Ürgün BM, Keçer M, Turşucu A, Genç S. Niksar, Erbaa ve Destek dolayının jeolojisi. MTA Der. No.8894, Ankara (unpublished); 1982. (in Turkish).

Arnorsson S, Gunnlaugsson E, Svavarsson H. The chemistry of geothermal waters in Iceland, III. chemical geothermometry in geothermal investigations. Geochim Cosmochim Acta. 1983;47:567-77.

Benderitter Y, Cormy G. Possible approach to geothermal research and relative cost estimate. In: Dickson MH, Fanelli M, editors. Small geothermal resources. Rome: UNITAR/UNDP Centre for Small Energy Resources; 1990. p. 61-71.

Clark I, Fritz P. Environmental isotopes in hydrogeology. New York: Lewis publishers; 1997.

Craig H. isotopic variations in meteoric water. Science. 1961;133:1702-3.

DeGroot-Hedlin C, Constable S. Occam's inversion to generate smooth, two-dimensional models form magnetotelluric data. Geophysics. 1990;55:1613-24.

Drahor MG, Berge MA. Geophysical investigations of the Seferihisar geothermal area, Western Anatolia, Turkey. Geothermics. 2006;35(3):302-20.

Drever JI. The geochemistry of natural waters. 3rd ed. New Jersey: Prentice Hall. Inc.; 1997.

Duru O, Keskin M. Kars Volkanik Platosu'nun Çıldır (Ardahan Ili) Kuzeyindeki Bölümünün Volkanostratigrafisi, Petrografisi ve Magmatik Ayrımlaşma Süreçleri, İstanbul Üniversitesi Mühendislik Fakültesi Yerbilimleri Dergisi 2014; 27:17-40. (in Turkish).

Ekmekçi M, Gültekin F. Doğu Karadeniz Bölümü Suları Çevresel Duraylı Izotop Içeriğinin Değerlendirilmesi, In: Ulusay R, Ekmekçi M, Ersoy H (eds) Ulusal Mühendislik Jeolojisi Sempozyumu (MÜHJEO 2015) bildiri kitabı, Trabzon, 2015; 2015. (in Turkish).

El-Qady G. Exploration of a geothermal reservoir using geoelectrical resistivity inversion: case study at Hammam Mousa, Sinai, Egypt. J Geophys Eng. 2006;3:114-21.

Erendil M, Turhan N, Aksoy A, Özdemir H, Sirel E. Artvin Dolayının Jeolojik Etüdü, MTA Derleme Raporu, Ankara, (unpublished); 1989. (in Turkish). 
Fournier RO. A review of Chemical and Isotopic Geothermometers for Geothermal Systems, In: Proceedings of the symposium on geothermal energy, Cento Scientific Programme, Ankara; 1977.

Fournier RO, Truesdell AH. Geochemical indicators of subsurface temperature, estimation of temperature and fraction of hot water mixed with cold water. J Res US Geol Survey. 1974;2:263-70.

Gemici Ü. Çeşme Yarımadası'nın Hidrojeolojisi ve Jeotermal Enerji Olanakları, Doktora Tezi. İmir: University of Dokuz Eylül; 1999 (in Turkish)

Geotomo Software. RES2DINV ver. 3.55, Malaysia http://www.geoelectrical.com. Accessed 20 June 2017.

Giggenbach WF. Geothermal solute equilibria. Derivation of Na-K-Mg-Ca geoindicators. Geochim Cosmochim Ac. 1988;52:2749-65.

Güven IH. Doğu Karadeniz Bölgesi'nin 1/250000 ölçekli jeolojik ve metalojenik haritası MTA, Ankara; 1993. (in Turkish)

Haenel R, Rybach L, Stegena L. Fundamentals of Geothermics. In: Haenel R, Rybach L, Stegena LA, editors. Handbook of terrestrial heat- flow density determination. Dordrecht: Kluwer Academic; 1988.

Hochstein MP. Classification and assessment of geothermal resources. In: Dickson MH, Fanelli M, editors. Small geothermal resources. Rome: UNITAR/UNDP Centre for Small Energy Resources; 1990.

Hounslow AW. Water quality data: analysis and interpretation. Boca Raton: CRC Press LLC, Lewis Publishers; 1995.

IAH (International Association of Hydrogeologists). Map of mineral and thermal water of Europe, Scale: 1:500.000. London: IAH; 1979

Innocenti F, Mazzuoli R, Pasquare G, Radicati F, Villari L. Tertiary and quaternary volcanism of the Erzurum-Kars area (Eastern Turkey). Geochronological data and geodynamic evolution. JVolcanol Geoth Res. 1982;13:223-40.

Kara I. Türkiye Termal ve Mineralli Sular Envanteri (Artvin), MTA, Derleme. Raporu. No: 10261, Ankara. (unpublished); 1997. (in Turkish)

Karaköse C, Asutay HJ, Yergök AF, Akbaş B, Dalkılıç H, Meng H, Kara H, Papak I, Keskin I. Ardahan-Posof Dolayının Jeolojisi, MTA Derleme Raporu No: 9962; 1994. (in Turkish).

Konak O, Yılmaz BS, Gülibrahimoğlu I, Yazııı EN, Yaprak S, Saraloğlu A, Köse Z, Çuvalcı F, Tosun CY. Artvin Ilinin Çevre Jeolojisi ve Doğal Kaynakları, MTA, Derleme Raporu No:10165, Ankara; 1998. (in Turkish).

Krouse HR. Sulphur isotopes in our environment. In: Fritz P, Fontes J, editors. Handbook of environmental isotope geochemistry l, the terrestrial environment. Amsterdam: Elsevier; 1980.

Langmuir D. Aqueous environmental geochemistry. Englewood Cliffs: Prentice Hall, Inc;; 1997.

Lloyd RM. Oxygen isotope behavior in the sulfate-water system. J Geophys Res. 1968;73:6099-110.

Loke $\mathrm{MH}$. Electrical imaging surveys for environmental and engineering studies, a practical guide to 2-D and 3-D surveys; 2000. http://www.geoelectrical.com. Accessed 20 June 2017.

Loke MH (2010) RES2DINV software. Geoelectrical imaging 2D and 3D. Instruction manual. Geotomo Software, http:// www.geotomosoft.com. Accessed 20 June 2017.

Majumdar RK, Majumdar N, Mukherjee AL. Geoelectric investigations in Bakreswar geothermal area, West Bengal, India. J Appl Geophys. 2000;45:187-202.

MGM (2017) Illerimize Ait Istatiski Veriler. http://www.mgm.gov.tr/veridegerlendirme/il-ve-ilceler-istatistik. Accessed 14 Mar 2017.

Mizutani Y, Rafter TA. Oxygen isotopic composition of sulphates, Part 3. Oxygen isotopic fractionation in the bisulphate ion-water system. New Zeal J ScI. 1969;12:54-9.

Muffler P, Cataldi R. Methods for regional assessment of geothermal resources. Geothermics. 1978;7:53-89.

Özürlan G, Şahin MH. Integrated geophysical investigations in the Hisar geothermal field, Demirci, Western Turkey. Geothermics. 2006;35:110-22.

Piper AM. A graphic procedure in geochemical interpretation of water analyses. Am Geophys Union Trans. 1944;25:914-23

Piscopo V, Barbieri M, Monetti V, Pagano G, Pistoni S, Ruggi E, Stanzione D. Hydrogeology of thermal waters in Viterbo area, central Italy. Hydrogeol J. 2006;14:1508-21.

Reynolds JM. An introduction to applied and environmental geophysics. Chichester: John Wiley and Sons Ltd; 1997.

Schaffer R, Sass I. The thermal springs of Jordan. Environ Earth Sci. 2014;72:171-87.

Schoeller H. Les Eaux Souterraines. Paris: Masson; 1962.

Şahinci A. Jeotermal Sistemler ve Jeokimyasal Özellikleri. İzmir: Reform Matbaasl; 1991 (in Turkish)

Tarcan G, Gemici Ü, Aksoy N. Hydrogeological and geochemical assessments of the Gediz Graben geothermal areas, western Anatolia. Turkey, Environ Geol. 2005;47:523-34.

Telford WM, Geldart LP, Sheriff RE. Applied geophysics. 2nd ed. Cambridge: Cambridge University Press; 1990.

Truesdell AH, Fournier RD. Procedure for estimating the temperature of a hot-water component in a mixed water by using a plot of dissolved silica versus enthalphy. J Res US Geol Surv. 1977;5:49-52.

Türkecan A. Türkiye'nin Doğu Bölgelerinde Gözlenen Kuvaterner Yașıı Volkanik Etkinlikleri, Doğal Kaynaklar ve Ekonomi Bülteni. 2017; 22: 63-78. (in Turkish).

Uzelli T, Baba A, Mungan GG, Dirik RK, Sözbilir H. Conceptual model of the Gülbahçe geothermal system, Western Anatolia, Turkey: based on structural and hydrogeochemical data. Geothermics. 2017;68:67-85.

Wu G, Hu X, Huo G, Zhou X. Geophysical exploration for geothermal resources: an application of MT and CSAMT in Jiangxia, Wuhan, China. J Earth Sci. 2012;23(5):757-67.

Yurteri C, Simsek Ş. Hydrogeological and hydrochemical studies of the Kaman-Savcllı-Büyükoba (Kırsehir) geothermal area, Turkey. Geothermics. 2017:65:99-112. 